\title{
UNA NUEVA FORMA DE HACER POLÍTICA: DAR LA VOZ A LA MILITANCIA ¿REALIDAD O MERA APARIENCIA?
}

ALEXANDRE H. CATALÁ I BAS 


\section{SUMARIO}

1. EL PROBLEMA: LOS EXCESOS DE LOS PARTIDOS POLÍTICOS. 2. LA SOLUCIÓN: DAR LA VOZ A LA MILITANCIA. 2.1. Asamblea de Afiliados o Congreso de compromisarios. 2.2. Primarias. ¿la panacea a todos los males? 2.3. Elección de otros cargos orgánicos. 2.4. La participación de la militancia en la elaboración de documentos políticos. 2.5. El papel de la militancia en la elaboración de las listas electorales. 2.6. Otros mecanismos de democracia directa y democracia participativa. 3. LIBERTAD DE EXPRESIÓN DE LOS MILITANTES. 4. ¿REALIDAD O MERA APARIENCIA? 


\title{
UNA NUEVA FORMA DE HACER POLÍTICA: DAR LA VOZ A LA MILITANCIA ¿REALIDAD O MERA APARIENCIA?
}

\author{
ALEXANDRE H. CATALÁ I BAS* \\ Profesor Titular de Derecho Constitucional \\ Universitat de València
}

\section{EL PROBLEMA: LOS EXCESOS DE LOS PARTIDOS POLÍTICOS}

El ya un tanto lejano 15-M conmocionó ¿aparentemente? los pilares de nuestro sistema de partidos. Engullida por una terrible crisis económica, la ciudadanía giró sus ojos hacia los partidos políticos y sus dirigentes considerándoles los responsables de la situación. Por toda España se oía un eslogan, «no nos representáis», dirigido contra aquellos que meses antes habían sido elegidos en las urnas creando una fractura entre una legitimidad de origen, que da los votos, y una legitimidad de ejercicio que otorga o retira la actuación diaria de aquellos que han sido elegidos para ocuparse de los asuntos concernientes a la res publica, de la que, incluso, se hizo eco la Audiencia Nacional en su sentencia de 31/2014, de 7 de julio relativa al intento de rodear el Parlament de Catalunya. Estos movimientos sociales clamaban por una regeneración democrática poniendo sobre el tapete como algo novedoso lo que PANEBIANCO señalaba ya como una fuente fundamental de conflicto en las sociedades actuales, el cleavage establishment/antiestablishment/castalanticasta ${ }^{1}$ enfrentando vieja política a nueva política y lanzando el mensaje de que había que jubilar a los partidos tradicionales y a sus líderes y sustituirlos por savia nueva ${ }^{2}$. Con el tiempo el resultado ha sido una

* Profesor Titular de Derecho Constitucional. Departamento de Derecho Constitucional, Ciencia Política y de la Administración. Facultad de Derecho. Universitat de València. Campus de los Naranjos, s/n. 46071 Valencia (España). Email: Alexandre.Catala@uv.es

PANEBIANCO, A., Modelo de partidos, Alianza, Madrid, 1995, p. 507.

Así puede leerse en el Documento político de Podemos, p. 35, «No nos podemos parecer a los partidos viejos».» La desconexión entre los viejos partidos del turno y la realidad de su pueblo ha operado por esta vía. Hemos visto a representantes de esos partidos dedicar mucho tiempo a defender su escaño o su cargo, sus privilegios y su jubilación dorada, su cuota de recursos y su aparato, su baronía o su 
reordenación de nuestro panorama político: Los tradicionales han perdido apoyos pero se han mantenido y han aparecido y consolidado nuevos partidos políticos nacidos al amparo de dichos movimientos sociales ${ }^{3}$.

Los nuevos partidos, especialmente Podemos, lanzaron un mensaje que caló entre los electores y que pronto asumieron en mayor o menor medida también los partidos tradicionales: «Hay que dar la voz a la militancia». Es decir, acabar con los tics oligárquicos de los partidos de forma que el poder emanara de las bases y no, como hasta ese momento, de la cúspide o aparato del partido, dando así verdadero cumplimiento al mandato contenido en el artículo 6 CE de que los partidos tengan una organización y un funcionamiento democrático ${ }^{4}$. La realidad nos muestra que los partidos políticos han aprovechado la centralidad política que ocupan en las democracias para desvirtuar los fines constitucionalmente atribuidos convirtiéndose en poderosas estructuras cuyos fines pueden no ser plenamente coincidentes con los de la ciudadanía. Afirmaba SCHMITT en este sentido, «que los grandes partidos, en su mayoría, son actualmente estructuras en parte dotadas de una firme organización y en parte plasmadas en un complejo social minuciosamente organizado, con burocracias influyentes, con un ejercicio de funcionarios remunerados con todo un sistema de organizaciones auxiliares y de socorro, a los cuales está ligada una clientela espiritual, social, y económicamente coherente» ${ }^{5}$, de ahí que, de acuerdo con el mismo autor, «ha de ponerse límites

familia. Ese tiempo es tiempo robado a la defensa de las necesidades del país y es lo que ha permitido hacer de la profesionalización de la política un lugar de privilegio. Mediante este camino, los partidos acaban convirtiéndose en agencias de colocación o en lugares donde desarrollar una carrera. Y es así como acaban finalmente intervenidos y cooptados por las élites». https://files.podemos.info/HihzerN5Ev.pdf.

3 El resultado no ha de sorprendernos. Claus OFFE ya advertía que los movimientos sociales se enfrentan a un dilema en su desarrollo: Hay un momento que no pueden desarrollarse más si no se autoorganizan como un partido político so peligro de ser absorbidos ellos y sus demandas por los partidos tradicionales. Con el tiempo se mimetizan con el ambiente político desapareciendo paulatinamente la diferencia entre nuevos y viejos partidos. El caso de los Verdes en Alemania es paradigmático. OFFE, C., Partidos políticos y nuevos movimientos sociales, Sistema, Madrid, 1992, pp. 109 y 247 y ss. Si comparamos los resultados de las elecciones generales, claramente se observa que la irrupción de los nuevos partidos dibuja un nuevo mapa político lejos de las amplias mayorías que obtenían los dos partidos tradicionales de ámbito estatal: PP y PSOE. En las elecciones generales de Diciembre de 2016 los resultados para el Congreso fueron los siguientes: PP: 123, PSOE: 90, Podemos: 43, Ciudadanos: 40, IU: 2. En las elecciones de junio de 2016: PP: 137, PSOE: 85, Podemos-IU: 45, Ciudadanos: 32. En las elecciones de abril de 2019: PSOE: 123, PP: 66, Ciudadanos: 57, Podemos-IU: 33, Vox: 24. En las elecciones de noviembre de 2019: PSOE: 120, PP: 89, Vox: 52, Podemos-IU: 26, Ciudadanos: 10. Lejos están estos resultados de las amplias mayorías que PSOE (Octubre de 1982: 202, Junio de 1986: 184, Marzo de 2008: 169) o PP (marzo 2000: 183, o noviembre de 2011: 186) cosechaban. También es cierto que en las elecciones generales de 2019 Podemos y Ciudadanos mostraron claros signos de debilitamiento, que se han repetido en las autonómicas gallegas y vascas de julio de 2020, (calificadas, por ejemplo, por el líder de Podemos de «derrota sin paliativos» https://twitter.com/matthewbennett/ status/1282419561212579841.), lo que plantea dudas e incertidumbres de cara al futuro.

4 MORODO, R., «Partidos y democracia: los partidos en la Constitución Española» en VVAA: Los partidos políticos en España, Labor, 1979, p. 5.

5 SCHMITT, K., La defensa de la Constitución, Tecnos, Madrid, 1983, p. 142. 
a ese excesivo robustecimiento del partido» ${ }^{6}$. Ello no obstante, no hay que dejarse arrastrar por este autor en la idea de acabar con el Estado de partidos «creando incluso otras fuerzas situadas fuera de los partidos y aun por encima de ellos» ${ }^{7}$. Y es que, como afirma LINZ, por muy obsoletos que estén, «sin los partidos políticos que organicen y estructuren en alguna medida la competencia por el poder en todos los niveles del gobierno (el transnacional, el Estado, el regional o el local), la democracia, especialmente en grandes sociedades urbanizadas, no es posible» ${ }^{8}$.

Los partidos políticos lucen las dos caras de Jano. Junto a las funciones que constitucionalmente tienen atribuidas (de acuerdo con el artículo $6 \mathrm{CE}$ : expresar el pluralismo político, concurrir a la formación y manifestación de la voluntad general y ser instrumento fundamental para la participación política) han desarrollado otras, a las que podríamos denominar disfunciones. VON BEYME, destacaba la existencia de unos déficits democráticos típicos en el seno de los partidos políticos. Entre los más importantes, señalaba los siguientes: 1. La participación de los miembros del partido en la formación de la voluntad intrapartidista es escasa. 2. Los congresos del partido, que se supone son la expresión de la voluntad institucional de la soberanía popular del partido, a menudo, son únicamente un mero órgano aclamativo. 3. Escaso cambio de titularidad de los cargos representativos. 4. Penetración en los partidos por los grupos de interés. 5. El perfil de las élites de los partidos se presentan cada vez más separados socialmente de la base ${ }^{9}$. En esa misma línea, aquí podemos señalar, entre otros, los siguientes:

1. Desvirtuar el principio de separación de poderes. Desde el momento en que el partido o la coalición ganadora conforma gobierno y tiene mayoría parlamentaria, las funciones parlamentarias quedan, en parte, diluidas ${ }^{10}$.

2. Su conversión en partidos colonizadores. En palabras de SARTORI, omnívoros partidos semejantes a un pulpo; sistema identificado a menudo bajo la denominación italiana de partitocracia, fenómeno calificado por este autor degeneración o patología de los partidos ${ }^{11}$ y definido como una «tiranía de partidos en la que el centro real del poder se ha desplazado y concentrado

6 Ídem, p. 145

7 Ídem. p. 167.

8 LINZ, J.J. «Teoría de la democracia. Los problemas de las democracias y la diversidad de democracias», en DEL AGUILA, R., VALLESPÍN, F., y otros, La democracia en sus textos, Alianza, 1998, p. 237.

9 VON BEYME, K, Los partidos políticos en las democracias occidentales, Centro de Investigaciones sociológicas, 1989, Madrid, pp. 308 y ss.

10 Así lo entienden entre otros DUVERGER, M., Los partidos políticos, Fondo de Cultura Económica, México, 1951, sexta reimpresión, 1979, pp. 419 y ss. o SANTAMARIA, J., «Las relaciones entre el Gobierno y Cortes en el anteproyecto», Estudios sobre el proyecto de Constitución, Centro de Estudios Constitucionales, Madrid, 1978, pp. 121.

11 SARTORI, G., «La ingeniería constitucional y sus límites», Teoría y Realidad Constitucional, núm. 3, 1999, pp. 81 y 82.

(C) UNED. Revista de Derecho Politico 
del gobierno y el parlamento, a los órganos de dirección de los partidos» ${ }^{12}$. Consecuencia de ello: «la hipertrofia de aquellas áreas en las que penetra la política y que después son politizadas» ${ }^{13}$. La realidad es que en España, los partidos, en último término, controlan los nombramientos de los altos cargos de la Magistratura y de la Fiscalía, de los miembros del Consejo General del Poder Judicial, del Tribunal Constitucional, del Tribunal de Cuentas, el Defensor del Pueblo, La Comisión Nacional del Mercado de Valores, del Consejo de Estado, y un largo etcétera.

3. Conversión en partidos adormidera. Nos encontramos ante lo que ARANGUREN denominaba una «democracia hacedera» consistente en votar periódicamente y, tras ello, hacer dejación de los asuntos públicos en manos de políticos profesionales ${ }^{14}$. HELD denuncia que los actuales partidos son la causa de la pasividad de la masa electoral ${ }^{15}$. En el mismo sentido SARTORI pondrá de relieve la apatía «falta de interés, elevado nivel de ignorancia, participación mínima» de la inmensa mayoría de los ciudadanos a pesar del aumento del nivel educativo de la población, lo que termina convirtiendo al ciudadano en idion, es decir, aquel que no se ocupa de los asuntos públicos ${ }^{16}$.

4. Partidos antipedagógicos. Ante adormecidos militantes y simpatizantes de partidos democráticos se posicionan los de partidos no democráticos, motivados y emotivamente aglomerados alrededor del partido y su líder carismático mostrando como advierte DUVERGER «no solo una adhesión política sino un compromiso absoluto con la causa» ${ }^{17}$. En este fenómeno se cierne un gran peligro para la democracia. Ante el rearme ideológico de los partidos neofascistas que afloran por toda Europa, los partidos democráticos están más preocupados por ganar elecciones, por mantener su maquinaria electoral engrasada o su red clientelar a pleno rendimiento que por defender la democracia haciendo pedagogía de la misma. El Frente Nacional asentado como auténtica alternativa en Francia, al igual que Alternativa por Alemania en Alemania, o en Austria el Partido por la Libertad no parecen hacer cambiar de rumbo a los partidos democráticos. En el bando democrático se produce el fenómeno que ya denunció LOEWESTEIN antes de la II Guerra Mundial: la pérdida de lealtad espiritual de los partidos democráticos; es decir, un estado de aletargamiento ideológico ${ }^{18}$. En definitiva y como advierte

12 SARTORI, G., Teoría de la Democracia, Vol I, Alianza Universidad, Madrid, 1988, p. 192.

3 Ídem p. 301.

14 ARANGUREN, J. L., «Ética comunicativa y democracia» en APEL, K.D; CORTINA, A, DE ZAN, J, y MICHELINI, D. (Eds): Ética comunicativa y democracia, editorial Crítica, 1991, p. 211.

15 HELD, D., Modelos de democracia, Alianza, Madrid, 1992, p. 192.

16 SARTORI, G., Teoría de la Democracia..., op. cit., p. 141 y Vol. 11, p. 352.

17 DUVERGER, M., Los partidos..., op. cit., p. 32

18 LOEWESTEIN, K., «Militant Democracy and fundamental rights I/II», American political science review, núm. 31, 1937, p. 423. 
MARTINEZ SOSPEDRA, especialmente en el caso español, los partidos hoy en día han abandonado «sus tareas de socialización política (...). Abandono que dificulta el desarrollo de una cultura democrática tanto en el seno de los partidos como en el resto de la sociedad» ${ }^{19}$.

5. Conversión en partidos desideologizados y mercantilizados. Un partido si desea ser competitivo, es decir, estar en disposición de luchar por el poder ha de intentar atraer a gran número de electores. Ello pasa por abandonar o suavizar las partes más controvertidas de su proyecto político a fin de elaborar uno que sea aceptable por la mayoría del electorado, a costa, eso sí, de perder parte de su identidad ideológica, lo que pasa, como señala OFFE, por una desactivación de sus miembros y una erosión de su identidad colectiva ${ }^{20}$. En ese afán recaudatorio electoral, el partido diseña un programa electoral al gusto del consumidor y los dirigentes se convierten en «generalistas» con capacidad de adecuarse a cualquier situación. ${ }^{21}$ Se pasa de una estrategia agresiva a una estrategia de adaptación para conquistar una cuota estable de mercado, tal como destaca PANEBIANCO. ${ }^{22}$ La arena política se convierte, como han puesto de relieve muchos autores, entre otros WEBER ${ }^{23}$, SCHUMPETER $^{24}$, TOURAINE ${ }^{25}$, SARTORI ${ }^{26}$, o VON BEYME ${ }^{27}$, en un mercado político y el programa político en una especie de folleto comercial cuya misión es atraer al mayor número de votantes. Se ha llegado a denominar a esta forma de hacer política de los partidos "partidos escoba» o «partidos atrapalotodo» (catch all parties), meras agencias electorales, en términos de KIRCHHEIMER ${ }^{28}$. Es patente, dirá OFFE, que la táctica del partido «trata precisamente de hacer el programa aceptable y elegible «para todos» y partiendo de ese lema, supondría un fallo dar la imagen (al amigo o al enemigo) de un partido especializado en términos socioculturales». Para los dirigentes políticos, en definitiva «no cuenta el porqué, ni el por quién, sino el que se vote así y no de otra manera.» ${ }^{29}$

19 MARTINEZ SOSPEDRA, M., Introducción a los partidos políticos, Ariel, Barcelona, 1996, p. 255.

20 OFFE, C., Partidos políticos y nuevos movimientos sociales, Sistema, Madrid, 1992, p.65.

21 Ídem: p. 66 y 99. En el mismo sentido vide LINZ, J.J., «Teoría de la democracia...», op. cit., pp. 236 y ss.

22 PANEBIANCO, A., Modelos..., op. cit., p. 57.

23 WEBER, M., Economía y Sociedad Vol. II Fondo de Cultura Económica, México, de. 1969, pp. 1076 y ss.

24 SCHUMPETER, J. A., Capitalismo, Socialismo y Democracia, Folio, Barcelona, 1984, pp.336 y ss.

25 TOURAINE, A., ¿Qué es la democracia?, Temas de Hoy, Ensayo, Madrid, 1994, p. 320.

26 SARTORI, G., Teoría de la Democracia..., op. cit., p. 114.

27 VON BEYME, K., Los partidos políticos..., op. cit., p. 196.

28 KIRCHHEIMER, O. en LENZ, K. y NEUMANN, F. (eds.), Teoría y Sociología críticas de los partidos políticos, Anagrama, Barcelona, 1988, p. 328 y ss.

29 OFFE, C., Partidos políticos..., op. cit. pp. 99 y 100. Vide igualmente VON BEYME, K., Los partidos..., op. cit. p.16 y 196 o DALH, R., La democracia..., op. cit. p. 33. 
6. Oligarquización, burocratización y clientelismo de los partidos. Todos parecen coincidir, doctrina, militantes..., en que los partidos son controlados por una élite endogámica. Será MICHELS uno de los autores más destacados a la hora de describir este fenómeno formulando su famosa Ley de hierro ${ }^{30}$. Distingue WEBER entre vivir de la política y vivir para la política. El objeto de los partidos, dirá este autor, consiste en la adquisición de votos en las elecciones. Están controlados por un núcleo de elementos interesados en la existencia de un partido reunido bajo un jefe o un grupo de prominentes y de articulación firme. Dicho núcleo controla todos los resortes del partido: elabora el programa, elige la forma del procedimiento y designación de los candidatos, etc. ${ }^{31}$. De acuerdo con OFFE, la burocratización interna de los partidos tiene dos riesgos importantes: primero, que la composición social del aparato difiere cada vez más, tanto de la composición social de la población en general como en particular de la base electoral del partido. Y, segundo, que de la profesionalización de la política del partido resulta la dominación política por parte de profesionales y ejecutivos del partido. Uno de los efectos que ello produce es la desactivación de los miembros de la base. ${ }^{32}$ Ahora bien, es ilusorio pensar en una sociedad actual en una clase política aficionada. Que existan estos problemas no supone que la solución está en una clase política aficionada. Destaca LINZ que el propio sistema, con un régimen severo de incompatibilidades que hace casi imposible compaginar actividad pública con privada, con una serie de dificultades para que el político se reincorpore a su profesión (entre otras, haber quedado sus conocimientos obsoletos), así como el aumento de tiempo que la política exige a los políticos, el aumento de cargas sobre sus vidas personales, la necesidad de amplios conocimientos, muchos de los cuales se adquieren con la experiencia en política, etc. hace que, pese a que muchos ciudadanos rechacen la profesionalización de la política, muchos de los que se dedican lo hagan como una actividad a largo plazo y casi a tiempo completo. ${ }^{33}$. La complejidad de nuestra sociedad demanda políticos profesionales y no meros aficionados o a tiempo parcial. La política absorbe todo el tiempo del político. El problema está en aquellos que no tienen otro horizonte profesional que la política. Una

30 MICHELS, R., Los partidos políticos, Amorrortu, Buenos Aires, 1969.

31 WEBER, M., Economía y Sociedad, Vol. II, op. cit., pp. 701 y ss., 1071 y 1089. Vide igualmente DUVERGER, M., Los partidos..., op. cit., pp. 181, 182; PANEBIANCO, A., Modelos..., op. cit., pp. 61 y ss.; o TOURAINE, A., ¿Qué es la democracia? ..., op.cit., p. 177. Este último llegará a afirmar que «la corrupción más fuerte es la que permite a los partidos elegir sus dirigentes de forma endogámica».

32 OFFE, C., Partidos políticos..., op. cit. p. 62.

33 LINZ, J.J., «Conclusiones: los partidos políticos en la política democrática. Problemas y paradojas» en MONTORO; J.R., GUNTHER, R., LINZ, J.J. (eds), Partidos políticos. Viejos conceptos y nuevos retos, Trotta, Fundación Alfonso Martín —escudero, 2007, pp. 291 y ss. 
cosa es el político profesional y otro el profesional de la política. El problema radica principalmente en este último.

7. Control sobre la opinión pública. La opinión pública, en palabras del TEDH, asumidas por nuestro Tribunal Constitucional, es un pilar esencial de todo sistema democrático ${ }^{34}$. Esta afirmación constituye, en palabras de RYSSDAL «la filosofía de base de toda la jurisprudencia del Tribunal relativa al artículo $10 \mathrm{CEDH}{ }^{35}$ y supone que «la libertad de expresión no es solamente una garantía contra las injerencias del Estado (derecho subjetivo) sino también un principio fundamental (objetivo) para la vida democrática» ${ }^{36}$. SARTORI afirma con razón que la autonomía de la opinión pública ha entrado en crisis transformándose en mayor o menor medida en prefabricada. Esa opinión pública puede nacer y de hecho, en muchos casos, nace de poderosos sectores económicos y sociales a los que la clase política y los media son permeables ${ }^{37}$, en lo que DEUTSCH denominó cascade model; es decir, una opinión se fabrica por los grandes sectores económicos y sociales, se transmite a los partidos y de allí a los media y así sucesivamente hasta llegar al gran público ${ }^{38}$. Las nuevas tecnologías, que podrían servir para acabar con esa manipulación corren el peligro de convertirse en instrumentos de desinformación. Se funciona a base de eslóganes, ahora especialmente vía Facebook, twitter, instagram o you tuve, impactantes pero superficiales, sin argumentos y que más que despertar el lado racional y reflexivo de las personas, buscan el sensacionalismo, el recurso al emocionalismo y, como señala SCHUMPETER, «cuanto más débil sea el elemento lógico de la formación de la opinión pública y más compleja la falta de crítica racional de la influencia racionalizadora de la experiencia y responsabilidades personales, mayores son las oportunidades para los grupos que persiguen fines interesados». ${ }^{39}$

8. La corrupción. Desgraciadamente es un fenómeno que ha aflorado en muchos partidos. Enriquecimiento personal, vías irregulares de financiación, puertas giratorias, perpetuación en los cargos, redes clientelares etc. En un sistema democrático, como destaca MENY aflora el fenómeno de la

34 Vide por todas, SSTEDH Handyside de 7 de diciembre de 1976, Sunday Times de 26 de abril de 1979, Lingens de 8 de julio de 1986, Müller de 24 de mayo de 1988, Oberchlick c. Austria de 23 de mayo de 1991, y SSTC 12/1982 de 31 de marzo, 105/1983, de 23 de diciembre; 13/1985, de 31 de enero; 51/1985, de 10 de abril; y 104/1986, de 17 de julio.

35 RYSSDAL, Rolv, "Jurisprudence de la Cour européenne des droits de l'homme sur la liberté d'expression garantie par la Convention européenne des droits de l' homme», Bulletin des Droits de l' Homme, 1997, vol. 7, p. 60.

36 OETHEIMER, M., L'harmonisation de la liberté d' expression en Europe. Contribution a l'étude de l' article 10 de la Convention européenne des droits de l' bomme et de son aplication en Autriche et au Royanme-Uni. Editions A. Pedone, 2001. p. 60.

37 SARTORI, G., Elementos de teoría política, Alianza, 1992, ed. 2012, p. 187.

38 DEUTSCH, K.W., Las relaciones internacionales, $2^{\circ}$ edición, Buenos Aires, Paidos, Cap. X.

39 SCHUMPETER, J., Capitalismo... op. cit. p. 336. 
corrupción desde el momento en que desaparece la ética pública basada en la dignidad humana y en los valores que alumbra el sistema democrático ${ }^{40}$ desde el momento en que el espacio público se convierte en mercado y se privatiza la política ${ }^{41}$.

La cuestión es que muchos de estos problemas se paliarían en gran medida si se llevara a término el mandato del artículo $6 \mathrm{CE}$ de que los partidos posean una organización y funcionamiento democráticos. Como dice LINZ, «la democracia interna del partido es vista como una cura para los males del partido» ${ }^{42}$. Ahora bien, como advierte COTARELO «los partidos suelen tratar de evadirse de toda forma de regulación, especialmente en lo que respecta a su funcionamiento interno» ${ }^{43}$. El tipo de organización de un partido determinará su funcionamiento y no puede pretenderse un funcionamiento democrático con una organización no democrática. Ahora bien, un partido político dotado formalmente de una organización democrática pero cuyo funcionamiento real no lo es, no solo es un fraude, sino que se convierte en grave peligro para la democracia, más si es un partido de gobierno. La falta de una auténtica democracia interna en el seno de los partidos repercutirá en el propio Estado dada su centralidad política, mantendrá BLANCO VALDES, puesto que dicha carencia incide en la calidad y permeabilidad democrática de las propias instituciones del Estado, lo que contribuye claramente a su deslegitimación ${ }^{44}$. La cuestión es que la exigencia de ese principio democrático ha de combinarse con el derecho de autoorganización que tiene todo partido político. De ahí que lo que puede exigirse al partido es un mínimum que FLORES GIMÉNEZ considera que ha de afectar a los siguientes elementos: a. El procedimiento de admisión y expulsión de los afiliados. b. Las competencias de una Asamblea periódica sobre las decisiones importantes. c. La protección de los derechos fundamentales de los afiliados, especialmente el ejercicio de la libertad de opinión 75 y ss.

40 Vide en este sentido PECES BARBA MARTÍNEZ, G., Ética, poder y derecho, C.E.C, 1995, pp.

41 De todos son conocidos casos como Lezo, Púnica, Eres de Andalucía, el 3\% de Ciu, etc. Los barómetros del CIS muestran que la corrupción está entre los principales problemas de los españoles. El de noviembre de 2018 señalaba que la corrupción y el fraude era el undécimo problema en importancia que arrastra España. http://www.cis.es/cis/export/sites/default/-Archivos/Marginales/3220_3239/3231/ es3231mar.pdf; el de noviembre de 2019 señalaba que es el quinto problema en importancia. http:// www.cis.es/cis/export/sites/default/-Archivos/Marginales/3260_3279/3267/es3267mar.pdf; en el de enero de 2020 ocupaba el puesto número 10. http:/www.cis.es/cis/export/sites/default/ Archivos/ Marginales/3220_3239/3238/es3238mar.pdf; en el de mayo de 2020, la corrupción baja al puesto número 12, ocupando los primeros puestos el coronavirus, la sanidad y el empleo por razones obvias. http://www.cis.es/cis/export/sites/default/-Archivos/Marginales/3280_3299/3281/es3281mar.pdf.

42 LINZ, J.J. «Conclusiones. Los partidos políticos..., op. cit. P. 298.

43 COTARELO, R., Los partidos políticos, Sistema, Barcelona, 1985, 1ª reimpresión 1996, p. 157. En el mismo sentido SOLOZÁBAL, ECHEVARRÍA, J.J., «Sobre la constitucionalización de los partidos políticos en el Derecho constitucional y en el ordenamiento español», Revista de Estudios Políticos, núm. 45, 1985 , p. 155.

44 BLANCO VALDÉS, R. J, «Democracia de partidos y democracia en los partidos» en GONZÁLEZ ENCINAR, J. J. (Coord.) Derecho de partidos, Espasa, Madrid, 1992, p. 45. 
pública libre. d. La competitividad entre líderes: la libre presentación de candidaturas y su elección (tanto para el ámbito interno como para las instituciones públicas). e. El principio de la mayoría. f. Los procedimientos electorales. g. Los mecanismos de control del poder ${ }^{45}$. Ese mínimum democrático ha de combinar la dimensión formal con la material de democracia. En este sentido, destaca, por ejemplo, NAVARRO MÉNDEZ que ha de fijarse el «conjunto de reglas de juego que determinan quiénes y cómo se ejerce el poder dentro del partido para evitar que las tendencias «naturales» a la oligarquización de los partidos consigan marginar el parecer de la mayoría para favorecer el interés de la clase dirigente». Junto a ello, «la referencia al respecto a los derechos fundamentales en el seno del partido completa esa visión formal o procedimental con un necesario elemento material o sustantivo»; por último, añadirá que «la noción de democracia exige la previsión de mecanismos de cooperación del pueblo en la gestación de las decisiones políticas» ${ }^{46}$.

La percepción de la ciudadanía es que los partidos políticos son un problema. Como afirma VIDAL PRADO «los partidos políticos han de ser instrumentos y no obstáculos. En una democracia el protagonismo principal debe corresponder a la sociedad, y no es bueno que ese protagonismo se traslade hacia los partidos ${ }^{47}$. Se repite como un mantra que hay que dar mayor protagonismo a las bases del partido en detrimento de sus élites ${ }^{48}$. En España, los principales partidos han reaccionado a esta exigencia adoptando medidas que buscan democratizar su funcionamiento dando más participación a los afiliados. Ello no obstante, y a pesar de esos esfuerzos, el Ránking 2017 sobre calidad democrática de los partidos políticos españoles elaborado por el grupo de trabajo Más Democracia concluyó por tercer año consecutivo en la baja calidad democrática de los partidos españoles, en comparación con las normas de funcionamiento requeridas en Alemania o Gran Bretaña. Se señalan entre

45 FLORES GIMENEZ, F., La democracia interna de los partidos políticos, Congreso de los Diputados, Madrid, 1991, p. 75 y ss.

46 NAVARRO MENDEZ, I., Partidos políticos y democracia interna, Centro de Estudios Políticos y Constitucionales, Madrid, 1999, pp. 76 y 77.

47 VIDAL PRADO, C., «El derecho de participación política y la representación», Revista Facultad de Derecho y Ciencias Políticas, No. 96, 1996, p. 103.

48 A título de ejemplo: «Gómez pide dar voz al militante del PSOE para volver a luchar contra 'los poderosos». https://www.elmundo.es/elmundo/2011/12/09/espana/1323440970.html. viernes 09/12/2011 15:38 horas «Dar la voz a la militancia es dar la voz a la democracia. Somos todos los que decidimos». Socialistas de la Vega Baja mueven ficha para «dar la voz a los militantes». https://www. diariodelavega.com/socialistas-de-la-vega-baja-mueven-ficha-para-dar-la-voz-a-los-militantes/. 15/12/2016. «Dar la voz a la militancia es dar la voz a la democracia. Somos todos los que decidimos». https://twitter.com/sanchezcastejon/status/702770467661324288. Arrimadas propone dar más protagonismo a los militantes de Cs si es presidenta del partido. https://www.europapress.es/nacional/noticia-arrimadas-propone-dar-mas-protagonismo-militantes-cs-si-presidenta-partido-20200119145843. html. 19/01/2020 14:58:43 +01:00CET. El exportavoz de Cs La Rioja, entre los críticos que piden dar más voz a la militancia y menos poder al Comité Ejecutivo. https://www.europapress.es/la-rioja/noticia-exportavoz-cs-rioja-criticos-piden-dar-mas-voz-militancia-menos-poder-comite-ejecutivo-20200131102833.html. 31/01/2020 10:28:33 +01:00

(C) UNED. Revista de Derecho Político

N. ${ }^{\circ} 109$, septiembre-diciembre 2020, págs. 73-118 
las principales causas de esta conclusión: 1. «Los congresos de los partidos se celebran muy mayoritariamente cada tres o cuatro años, lo que obstaculiza la renovación de sus políticas e ideas, así como de sus dirigentes e impide a las oposiciones internas plantear alternativas». 2. «Las reuniones de los órganos de control de las direcciones son poco frecuentes y no controlan a sus órganos directivos o tienen apenas capacidad para hacerlo. Hay un incumplimiento de estos órganos previstos en los propios Estatutos. Esto hace que la función de contrapeso de las direcciones haya desaparecido en algunos partidos». 3. «Los derechos de los afiliados se reconocen en los Estatutos, pero no se han implementado sistemas eficaces para defenderlos». Y 4 «Los sistemas de selección de los candidatos a cargos públicos giran en torno a las decisiones de los órganos de dirección ${ }^{49}$.

\section{LA SOLUCIÓN: DAR LA VOZ A LA MILITANCIA}

Ante este escenario de deslegitimación de los partidos políticos, actual, aunque no de reciente aparición, la mayoría de ellos han reaccionado implantando una serie de medidas que, sobre el papel, pretenden democratizar su funcionamiento interno dando, en última instancia, mayor protagonismo a las bases, todo ello como medida de regeneración democrática. Con ello se quiere transmitir la idea de que el poder fluye de abajo arriba y no al revés. Pasemos a analizar, aunque sea someramente, algunas de las medidas que los principales partidos han adoptado en este sentido. En este trabajo se han analizado los Estatutos y otros documentos del PSOE, Partido Popular, Podemos, Ciudadanos y Vox,

\subsection{Asamblea de afiliados o Congreso de compromisarios.}

Tradicionalmente el máximo órgano de los partidos políticos han sido los Congresos participados por compromisarios. Rara vez en este tipo de reuniones se plantean auténticos debates. Lejos quedan Congresos como el XXVIII Congreso del Partido Socialista Obrero Español que se celebró en mayo de 1979 y el Congreso extraordinario de septiembre de ese mismo año. Actualmente los Congresos se han convertido, en la mayoría de ocasiones, en palabras de LINZ, en meros «eventos mediáticos ${ }^{50}$. Por otra parte, los partidos suelen caer en la tentación de controlar la designación de los compromisarios. Como advierte FLORES JIMÉNEZ, «la selección democrática de compromisarios rara vez existe» ${ }^{51}$. Se ejerce un control de arriba a abajo por lo que en la selección de representantes de «abajo arriba» rara vez existe

${ }^{49}$ http://mas-democracia.org/wp-content/uploads/2017/07/Ranking-2017-calidad-democra\%CC\%81tica.pdf

50 LINZ, J.J., «Conclusiones: los partidos políticos en la política democrática..., op. cit., p. 299.

51 FLORES GIMÉNEZ, F., La democracia interna..., op. cit. p. 131 
la selección democrática. Es mucho más fácil controlar al compromisario que al afiliado. La conformación del máximo órgano del partido no como congreso de compromisarios sino como asamblea de afiliados, e incluso de simpatizantes, es visto como un ejemplo de devolver el protagonismo a las bases y romper con la idea del carácter oligárquico del partido. A esta cuestión los partidos han respondido de diferente manera.

- El PSOE ha optado, de acuerdo con el artículo 17 de sus Estatutos, por mantener un Congreso de delegados.

- De igual manera, el artículo 33 de los Estatutos del Partido Popular, el máximo órgano del partido es el Congreso formado por compromisarios ${ }^{52}$.

- Ciudadanos opta también (artículo 57) por una Asamblea de Compromisa$\operatorname{rios}^{53}$.

- Podemos opta (artículo 13 de sus Estatutos) por una Asamblea General de todos los afiliados ${ }^{54}$.

- De igual manera, Vox establece como órgano supremo del partido, artículo 11, la Asamblea General formada por el conjunto de afiliados ${ }^{55}$.

\subsection{Primarias, ¿la panacea a todos los males?}

Los propugnadores de la «nueva política» que pretende acabar con los males de la «vieja política» ven en las primarias el gran remedio contra todos los defectos que arrastran los partidos. Se considera la aplicación de esta «nueva» fórmula como el remedio a todos los males cuando, lo cierto es que las primarias forman parte de la vieja política tanto como la elección por medio de compromisarios o representantes. Lo primero que hay que dejar claro que la elección de determinados cargos orgánicos, principalmente el secretario general o el presidente del partido, ya sea a nivel nacional, autonómico, provincial o local, no es, en puridad, unas primarias, sino una elección directa por los militantes de un cargo orgánico. Por eso se les ha venido en denominar "primarias internas» ${ }^{56}$. El concepto de primarias ha de reservarse para la elección del candidato electoral ${ }^{57}$.

52 http://www.pp.es/sites/default/files/documentos/estatutos_definitivos.pdf

53 Desaparece la posibilidad contemplada en los Estatutos de 2017, artículo 19.1., de que la Asamblea General pudiera constituirse directamente con los afiliados.

54 https://podemos.info/wp-content/uploads/2015/05/estatutos_de_podemos.pdf

55 https://www.voxespana.es/wp-content/uploads/2020/04/ESTATUTOS-CAMBIOS-PROPUESTOS-CEN-02-03-2020-1.pdf. 27 de julio de 2020. 10.00h.

56 Así, por ejemplo: Vox anuncia la celebración de primarias internas para renovar su dirección, presidida por Abascal. https://www.europapress.es/nacional/noticia-vox-anuncia-celebracion-primarias-internasrenovar-direccion-presidida-abascal-20200206210032.html. Madrid 06/02/2020 21:00:32 CET.

57 Vide en este sentido STEPHENSON, D. G., The right to vote, ABC-CLIO, Santa Bárbara, 2004, p.49. En el mismo sentido PEREZ MONEO, M., La selección de candidatos electorales en los partidos. Centro

(C) UNED. Revista de Derecho Politico

N. ${ }^{\circ} 109$, septiembre-diciembre 2020, págs. 73-118 
En España, esta forma de elegir al candidato electoral ni tiene mucha tradición ni es unánime. Fue tras el XXXIV Congreso Federal del PSOE de 1997 cuando se aprobó, el 21 de marzo de 1998, por parte del Comité Federal, no de la militancia, un nuevo Reglamento de Selección de Candidatos y Candidatas a Cargos públicos. Este Reglamento introducía como novedad un sistema de primarias para la designación del candidato del partido a la presidencia del gobierno de la Nación, de los gobiernos autonómicos, alcaldes de las principales ciudades y candidatos a presidencias de Consejos y Cabildos insulares y a Juntas Generales. Se enfrentaron dos miembros de la élite del partido: Joaquín Almunia, candidato oficial, contra Josep Borrell. El candidato oficialista perdió las primarias pero Josep Borrell nunca llegó a ser el candidato del PSOE en las generales que se avecinaban; dimitió tras el clásico fuego amigo $^{58}$. Vistos los perturbadores resultados, en palabras de BLANCO VALDES, del experimento bastaron para que el PSOE volviera sobre sus pasos y optara por su supresión. En opinión de este autor, así cabe interpretar el acuerdo del Comité Federal del PSOE de 11 de julio de 1998 en virtud del cual no habría primarias allí donde el partido gobernase en el momento en que aquéllas deberían celebrarse ${ }^{59}$.

Primarias ¿por qué y para qué? En cuanto a la primera pregunta, la opinión mayoritaria es que las primarías aparecen en momentos de crisis ya sean endógenas o exógenas al partido. En el PSOE, las primeras fue un cúmulo de factores tales como, la perdida de las elecciones generales, la crisis de liderazgo tras la salida de Felipe González y de Alfonso Guerra, la corrupción que azotaba al partido, etc. Para acometer un cambio de esta magnitud hacía falta un $s h o c k^{60}$, y es lo que sucedió al PSOE en aquella época. El resurgir de las primarias ya entrada la primera década del 2000 se debió, en gran medida, a la aparición de nuevos partidos propiciados por la grave crisis económica durante la segunda legislatura de Rodríguez Zapatero que representaban una nueva forma de hacer política y que achacaban todos los males a la clase política tradicional.

¿Para qué? En teoría, para llevar a cabo una regeneración democrática devolviendo, si alguna vez lo tuvieron, el poder a las bases. Opina BLANCO VALDÉS, que esta medida contribuiría a transformar la actual oferta oligárquica que canalizan los partidos en una oferta democrática ${ }^{61}$. Para este autor las primarias son una solución que podrían «no sólo mejorar el nivel de consenso partidario respecto de las élites que

de Estudios Políticos y Constitucionales, Madrid, 2012, p. 261.

58 Sobre aquellas primarias en el PSOE vide BOIX, Carles: Las elecciones primarias en el PSOE, Claves de Razón Práctica, n. ${ }^{\circ} 83,1998$, pp. 34 y ss., VARGAS MACHUCA, R., «A vueltas con las primarias del PSOE»Claves de Razón Práctica, n. ${ }^{\circ}$ 86, 1998 , pp. 11 y ss. BLANCO VALDES, R. L., Las conexiones políticas, Alianza, Madrid, 2001, pp. 86 y ss.

59 Ídem p. 105. Recuerda que IU ensayó «sin entusiasmo, y sin sobresaltos» este procedimiento en enero de 1996 para la lista de candidatos de Madrid para las generales de ese año y que, en definitiva (la obra es de 2001) no parecía en aquel entonces que este procedimiento llegara a generalizarse. Ídem. 111p.

60 VARGAS MACHUCA, R., Ibídem, p. 15.

61 BLANCO VALDÉS, R. L., Las conexiones políticas, Ensayo, 2001, p. 45. 
ocupan cargos representativos, sino que podría también, quizá, contribuir a favorecer un proceso de afiliación a los partidos, en la medida en que los ciudadanos percibieran que su adhesión estaría en condiciones de ofrecerles una oportunidad real de participar en la selección de los líderes políticos de la que carecían fuera del partido. Finalmente sería posible que ello redundase, incluso, en un aumento de la participación electoral» ${ }^{62}$. Pasados los años, puede observarse que algunos de estos objetivos no se han cumplido. Cabe cuestionarse, al menos en el sistema español, que «quien aspire a un puesto en la lista electoral no depende de los dirigentes del partido no necesitando tener un nombre propio para darse a conocer, sino que es el procedimiento el que le confiere una gran visibilidad a los que concurren en él por lo que los aspirantes desconocidos pueden tener una oportunidad para hacerse un nombre y concurrir en igualdad de condiciones con políticos más experimentados ${ }^{63}$, y es que es muy difícil que el candidato que surge, anónimo, directamente de las bases triunfe. Lo normal es que lo haga un candidato conocido y ello pasa por formar parte y/o estar apoyado por la élite del partido. A pesar de haberse generalizado el proceso de primarias, lo cierto es que el líder del partido acaba siendo el candidato electoral. Primarias y primarias internas acaban siendo ganadas por la misma persona ${ }^{64}$.

Los artículos 37 y siguientes de la Normativa Reguladora de los Cargos Públicos del PSOE establece un procedimiento de primarias para la selección de la candidatura a la presidencia del Gobierno de la Nación, las presidencias de las Comunidades Autónomas, presidencias de las Ciudades Autónomas, presidencias de los Cabildos, Presidencias de los Consejos Insulares, Presidencias de Juntas Generales y las alcaldías de determinados municipios ${ }^{65}$.

De acuerdo con el artículo 35.4 de los Estatutos del Partido Popular, el Presidente Nacional del Partido Popular, elegido por el Congreso, será el candidato del Partido a la Presidencia del Gobierno. No hay, pues, primarias para elegir al candidato a la presidencia del gobierno en el Partido Popular sino designación automática en favor del líder del partido. En este caso, y como a continuación veremos, el líder del partido tampoco es elegido directamente por la militancia.

En cuanto a Podemos, de acuerdo con el artículo 14 de sus Estatutos, corresponde a la Asamblea ciudadana «elaborar las listas electorales para optar a cargos públicos para las instituciones de representación de carácter estatal, mediante la celebración de elecciones primarias y abiertas a todas las personas afiliadas a Podemos». En este sentido, el Reglamento de Primarias para Congreso y Senado ${ }^{66}$, establece en su artículo 11 que se realizará una votación uninominal para elegir al candidato que enca-

62 Ídem, p. 47.

63 PÉREZ MONEO, M., La selección de los candidatos, op. cit. p. 291.

64 Una sistematización de los efectos de las primarias puede verse en PÉREZ MONEO, M., $L a$ selección de los candidatos, op. cit. y BOIX, C., Las elecciones primarias..., op. cit.

65 http://web.psoe.es/source-media/000000212000/000000212157.pdf. Advertir que este documento no aparece en la actual página web del PSOE.

66 https://podemos.info/wp-content/uploads/2018/11/Reglamento_primarias_estatales.pdf

(C) UNED. Revista de Derecho Politico

N. ${ }^{\circ} 109$, septiembre-diciembre 2020, págs. 73-118 
bezará la lista. Las primarias de Podemos para el Congreso de los Diputados se llevarán a cabo en la circunscripción. Es decir, cualquier persona inscrita podrá votar a cualquiera de las personas candidatas, independientemente de la circunscripción en la que las primeras estén inscritas o por la que las segundas se presenten. A nadie escapa que con este sistema se resta fuerza a las estructuras territoriales y asegura al partido un cierto control sobre las candidaturas.

En cuanto a la formación Ciudadanos, el artículo 101.1.de los Estatutos de 2020, tras la salida de Albert Rivera de la Presidencia del partido, establece un sistema de primarias para elegir al candidato a Presidente del Gobierno de España, a los candidatos a Presidentes de los gobiernos autonómicos, a los candidatos a las alcaldías de las capitales de provincia y municipios a así como de las presidencias de los cabildos insulares y Juntas Generales, y los cabezas de listas de las circunscripciones electorales de las elecciones generales, autonómicas y europeas, con el mismo requisito.

En cuanto a VOX, de acuerdo con el artículo 24 de sus Estatutos, tras la consulta a los Comités Ejecutivos Provinciales y de Ciudad Autónoma, será el Comité Ejecutivo Nacional el que apruebe las listas de los candidatos definitivos en las elecciones generales y europeas. En relación a las elecciones autonómicas, de ciudad autónoma, insulares y municipales, tras la propuesta de los Comités Ejecutivos Provinciales y de Ciudad Autónoma, será el Comité Ejecutivo Nacional el que apruebe las listas definitivas de candidatos.

\subsection{Elección de cargos orgánicos}

\subsubsection{Líder del partido}

De acuerdo con el artículo 5.1.b) de los Estatutos del PSOE, el/a Secretario/a General de las Comisiones ejecutivas insulares, provinciales, autonómicas y federal serán elegidos mediante primarias a doble vuelta regulándose igualmente un proceso de revocación o censura que requerirá, de acuerdo con el artículo 5 bis «ser motivado y acordado, mediante votación secreta, por un mínimo del $51 \%$ de votos del Comité Federal u órgano equiparable a otro nivel territorial; adoptado el acuerdo de inicio del proceso de revocación, la remoción de la persona titular de la Secretaría General deberá ser aprobada por la militancia y afiliado/as directos/as del respectivo ámbito de consulta (...) por mayoría de los votos emitidos» ${ }^{67}$.

67 Las últimas que tuvieron lugar en mayo de 2017 enfrentaron a Susana Díaz, a Pedro Sánchez y a Patxi López. Sánchez consiguió el 50,21\% de los votos frente al 39,94\% de Díaz: más de 15.000 sufragios de diferencia. Patxi López se quedó en el 9,85\% con 14.500 votos. Gran parte de los medios coincidieron en que «las bases se impusieron al aparato». Primarias PSOE Pedro Sánchez arrolla a Susana Díaz en las primarias del PSOE. https://www.elmundo.es/espana/2017/05/21/5920ac44268e3e1d6d8b4576. html. Madrid, 22 MAY. 2017 08:29. Contra todo pronóstico, los militantes del PSOE dijeron no este domingo a la vieja guardia, no a los barones, no a Susana Díaz y no al «PSOE de siempre» que ella pretendía restaurar». 
Los Estatutos del Partido Popular diseñan un sistema complejo para la elección del presidente del partido. La elección del Presidente Nacional y de los Presidentes Autonómicos, Provinciales e Insulares del Partido Popular se llevará a cabo en el Congreso del Partido mediante compromisarios elegidos en listas abiertas. Los precandidatos son elegidos directamente por la militancia siendo proclamados candidatos a la presidencia del Partido, los dos precandidatos que hubiesen obtenido el mayor número de los votos válidos emitidos por los afiliados salvo si alguno de los precandidatos obtuviese más del $50 \%$ del total de los votos válidos emitidos por los afiliados, hubiese logrado una diferencia igual o superior a 15 puntos sobre el resto de precandidatos y hubiera sido el más votado en la mitad de las circunscripciones, en cuyo caso será proclamado ante el Congreso como candidato único a la Presidencia del Partido $^{68}$. Los Congresos elegirán también, junto a los candidatos, a quienes les acompañen para ostentar las funciones de dirección, mediante el sistema de voto mayoritario a una sola vuelta.

En cuanto a la formación política Podemos, de acuerdo con el artículo 26, en relación con el artículo 14, «la persona que ocupe la Secretaría General será elegida por la Asamblea Ciudadana estatal de Podemos, mediante sufragio libre y directo ${ }^{69}$. De igual manera, el artículo 42, en relación con el artículo 34 establece similar procedimiento para la elección de la persona que ha de ocupar la Secretaría General Autonómica. Para el ámbito municipal, para aquellos municipios con 50 militantes o menos, el artículo 50, en concordancia con los artículos 46 y 55, señala que la Secretaría General Municipal se elegirá mediante primarias abiertas; y para los municipios con más de 50 militantes, el artículo 51 en relación con los artículos 46 y 55 también establece que este cargo se elegirá mediante primarias abiertas.

En cuanto a la revocación, el artículo 26 en relación con el artículo 14 establece que la persona que ocupe la Secretaría General podrá ser revocada «mediante consulta a tal efecto ante la Asamblea General Ciudadana en la forma establecida en los presentes Estatutos. De forma similar, el artículo 42 en relación con el 34 para la persona que ocupe la Secretaría General Autonómica. En cuanto al ámbito municipal se seguirá el mismo sistema, tal como se desprende del artículo 55 en relación con los artículos 46, 50 y 51.

Por lo que respecta a Ciudadanos, tal como se deriva de los artículos 78 y 69.1 . el Presidente es elegido junto a su Comité Ejecutivo en una lista cerrada mediante

68 De esta manera, en las primarias internas de Julio de 2018, en primera vuelta, en la que votaban por primera vez los afiliados, se obtuvieron los siguientes resultados: Santamaría (21.513), Casado (19.967), Cospedal (15.090), Margallo (680), Hernández (668) y Cabanes (185) pasando a la segunda vuelta los dos primeros. Como dato significativo advertir que solo 66.706 miembros del PP de los 869.535 afiliados por el partido se habían registrado para votar en la elección. La segunda vuelta se celebró en el XIX Congreso del PP entre los delegados del partido del 20 al 21 de julio. Finalmente, Pablo Casado fue elegido presidente del Partido Popular con el $57.2 \%$ de los votos de los compromisarios.

${ }^{6}$ El 21 de myao de 2020 tuvo lugar la renovación del líder de Podemos. En esta ocasión la lista que encabezó Pablo Iglesias obtuvo 53.167 votos, el 92,2\% de los sufragios emitidos, de un total de 59.201 inscritos que ejercieron su derecho a voto de manera telemática.

(C) UNED. Revista de Derecho Político

N. ${ }^{\circ} 109$, septiembre-diciembre 2020, págs. 73-118 
una votación del conjunto de afiliados ${ }^{70}$. Reaparece en los Estatutos de 2020 la moción de censura, artículo 69.3., que deberá ser promovida por un tercio de los afiliados y aprobada por mayoría absoluta de la Asamblea General ${ }^{71}$.

En cuanto a VOX, de acuerdo con el artículo 23 sus Estatutos, el Presidente nacional será elegido, junto al resto de miembros de su candidatura al Comité Ejecutivo Nacional, por la Asamblea General que, de acuerdo con los artículos 11 y 12, está constituida por el conjunto de afiliados que actuarán personal y directamente ${ }^{72}$. Similar procedimiento se sigue para la elección de Presidente y resto de los Comités Ejecutivos provinciales y de Comunidad Autónoma. El artículo 26 prevé la posibilidad de que cualquier presidente de Comité Ejecutivo pueda someterse una cuestión de confianza y que cualquier afiliado pueda plantear una moción de censura siempre y cuando la acompañe del aval de las $2 / 3$ partes de los afiliados de pleno derecho del ámbito territorial en que ejerza sus funciones el Comité cuestionado. Requisito muy difícil de cumplir. Por ello, posiblemente, los Estatutos solo exigen mayoría simple para que la moción triunfe.

\subsubsection{Elección de otros cargos orgánicos}

En el PSOE, las Comisiones Ejecutivas Municipales y de Distrito, serán elegidas por medio del sistema de voto mayoritario, mediante voto, individual, directo y secreto de todos los militantes en las listas cerradas y bloqueadas. Llama la atención en un sistema proporcional como el nuestro, que asegura la presencia de mayoría y minoría en los órganos representativos, esta forma de elección que otorga todos los puestos a la mayoría. Un sistema mayoritario en listas cerradas y bloqueadas deja sin presencia a la minoría, lo que no es precisamente un ejemplo de calidad democrática.

70 Las primarias que tuvieron lugar en marzo de 2020, Inés Arrimadas se impuso a su rival, Francisco Igea, con el 76,91\% de los votos. En este caso «Los militantes decidieron continuidad en vez de ruptura: la corriente crítica, que recogió el descontento por el desplome electoral del 10-N y el hiperliderazgo de Rivera, logró el 22\% de los votos.» Ciudadanos. Arrimadas gana las primarias y se convierte en presidenta de Ciudadanos. https:/elpais.com/espana/2020-03-08/arrimadas-gana-las-primariasy-se-convierte-en-presidenta-de-ciudadanos.html. Madrid - 08 MAR 2020 - 23:31 CET.

71 En la versión de 1 de noviembre de 2014, el artículo 4.6 señalaba en su punto 1 que los Presidentes y Coordinadores de los distintos órganos del Partido, así como los del resto de los integrantes de sus mesas de gobierno o Consejos Directivos y los de los representantes de las Agrupaciones y Comités Territoriales en órganos superiores «podrán ser revocados por el mismo cuerpo electoral que los eligió mediante la presentación y aprobación de una moción de censura». La posibilidad de presentar mociones de censura desaparecía en los Estatutos de 2017 aunque en el Reglamento de organización del mismo año se contemplaba para las Juntas directivas de las agrupaciones locales.

72 El 7 de marzo de 2020 Santiago Abascal fue elegido, sin oposición, sin votación y a puerta cerrada, líder de Vox en una Asamblea polémica en la que se restringió la entrada de afiliados ya que sólo pudieron acceder al recinto de la Plaza de Vistalegre los cargos públicos y orgánicos. Vox: Vox reelige a Abascal sin votación en una asamblea cerrada a los críticos. https://elpais.com/espana/2020-03-07/voxreelige-a-abascal-sin-votacion-en-una-asamblea-cerrada-a-los-criticos.html. Madrid - 07 MAR 2020 - 22:26 CET. 
En cuanto a los miembros de la Comisión Ejecutiva de ámbito insular, provincial, autonómico y federal, serán elegidos mediante sistema mayoritario, a propuesta del/ la Secretario/a General por voto individual, directo y secreto, de todos/ as los/as delegados/as con derecho a voto del Congreso respectivo.

El Comité Federal, de acuerdo con los artículos, 5.2 y 31 tiene unos miembros natos, controlados en su mayoría por el aparato del partido y una serie de miembros a elegir: 132 miembros, que será un tercio del número total de sus miembros, elegidos por el Congreso Federal, mediante voto individual, directo, secreto de los/as delegados/as del Congreso en listas cerradas y bloqueadas, pudiendo, de acuerdo con el artículo 5.2..a.i., acceder la minoría a formar parte de ese órgano siempre que obtenga como mínimo un $20 \%$ de los votos, afirmándose a continuación que «en todo caso, la lista que obtenga la mayoría tendrá derecho a la mitad más uno de los/as delegadas a elegir y en el caso de que ninguna lista obtengas a mayoría, será la más votada la que goce de este privilegio; otro tercio elegido por los Congresos Regionales o Nacionales y un último tercio elegidos por los militantes del PSOE y afiliados/as directos/ as. Este sistema se reproduce, de acuerdo con el artículo 5.2 para la elección de los miembros de los Comités Provinciales, Insulares, Regionales o Nacionales. Por lo tanto, solo un tercio de los miembros de estos órganos es elegido directamente por la militancia. Por otra parte, discutible es, al menos, el «privilegio» que se otorga a la lista mayoritaria o más votada que resta pluralidad en la composición del órgano.

La militancia no participa directamente ni en la designación de miembros del Consejo Político Federal, todos ellos cargos orgánicos, si observamos el artículo 42.1.b., ni en la de Comisión Federal de Listas que, de acuerdo con el artículo 44, está formada por los miembros de la Comisión Ejecutiva Federal y miembros del Comité Federal, ni en la Comisión Federal de Ética y Garantías, que serán elegidos, a la vista del el artículo 45, elegidos en el Congreso Federal del Partido.

En cuanto al Partido Popular. De acuerdo con el artículo 33, los Congresos del Partido, sea cual sea su ámbito territorial, estarán constituidos por los siguientes compromisarios: a) Natos: que lo serán todos los miembros de la Junta Directiva convocante y los miembros de la Comisión organizadora y b) electos, en número cuatro veces superior al de los natos elegidos por las organizaciones territoriales mediante un sistema de lista abierta, lo que sí da voz a la militancia en este punto. La militancia no interviene en la elección del Secretario General, que será nombrado por el Comité Ejecutivo, a propuesta del Presidente, de entre los miembros elegidos para este órgano por el Congreso del Partido, ni de los miembros de la Junta Directiva Nacional, máximo órgano de dirección del Partido entre Congresos, ni de los miembros de los Comités Ejecutivos (Nacional, Regionales, Provinciales o insulares), órganos de gobierno y administración del partido entre Congresos, ni de los miembros del Comité de Dirección Nacional, órgano de gestión y coordinación de las tareas ordinarias del Partido, en el marco de las directrices del Comité Ejecutivo Nacional, ni de los miembros de los Comités electorales. 
Pasemos a Podemos. La mayoría de los miembros del Consejo Ciudadano, de acuerdo con el artículo 14 en relación con el artículo 24 es elegido por la Asamblea Ciudadana mediante primarias abiertas que tiene la potestad de revocarlo. El Consejo de Coordinación estatal será elegido, de acuerdo con el artículo 27, por el Consejo Ciudadano, de entre sus miembros, por mayoría simple; igualmente, el autonómico, de acuerdo con el artículo 43, será elegido por el Consejo Ciudadano de entre sus miembros también por mayoría simple. En cuanto a los miembros del Consejo de Coordinación Municipal, serán elegidos por la mayoría del plenario, a propuesta de la Secretaría General Municipal. Por último, las Comisiones de Garantías Disciplinarias, la estatal y las autonómicas, serán elegidas, de acuerdo con los artículos 14 y 34 y 68, directamente por la Asamblea Ciudadana mediante voto directo entre candidaturas que podrán ser agrupadas en listas abiertas no necesariamente completas. Las Asambleas tienen la capacidad de revocarlas. Por lo tanto, salvo el Consejo de Coordinación, el resto de los órganos es elegido por la militancia que se reserva la facultad de revocarlos total o parcialmente lo que viene a ser ejemplo de apertura a las nuevas exigencias de la sociedad. Indudablemente, y sobre el papel, es el partido que más voz da a la militancia y por ello el de mayor calidad democrática en su funcionamiento.

Por lo que respecta a Ciudadanos, Veamos, en primer lugar, los órganos nacionales colegiados. La Asamblea General, artículo 57, está formada, en principio, por compromisarios y por cargos orgánicos ${ }^{73}$. En cuanto al Consejo General, máximo órgano político del partido entre Asambleas Generales, de acuerdo con el artículo 62 estará formado por los integrantes del Comité Ejecutivo hasta un máximo de veinte, por los Coordinadores de los Comités autonómicos y por 125 miembros son elegidos por la Asamblea General mediante un sistema de listas abiertas. El Comité Ejecutivo, que según el artículo 67 es, bajo la presidencia del presidente del partido, el órgano de dirección, gobierno y administración del partido entre Asambleas, es elegido, de acuerdo con el artículo 69 por todos los afiliados con derecho al sufragio mediante voto libre, secreto y listas cerradas siendo elegida la lista más votada ${ }^{74}$, sistema mayoritario que deja fuera a la o las minorías. Los miembros del Comité Permanente, órgano de gestión y coordinación de actividades ordinarias del partido, son nombrados por el presidente de entre los integrantes del Comité Ejecutivo (artículo 74). En

73 Desaparece la posibilidad contemplada en los Estatutos de 2017, artículo 19.1., de que pudieran actuar los afiliados directamente lo que supone un retroceso en lo que se refiere a la participación de la militancia.

74 En los Estatutos de 2017 se especificaba, artículos 19.10.d) y 25.9, que era la Asamblea General «constituida, en todo caso, por el conjunto de afiliados» la que elegía al Comité ejecutivo. El vigente artículo 69 señala que «la elección del Comité ejecutivo tendrá lugar una vez convocada la Asamblea general, y con una antelación no superior a quince días a su celebración». No denomina de ninguna manera esa reunión de todos los afiliados. Ello no obstante, el artículo 18.f) reconoce el derecho del afiliado a «A asistir, como compromisario, a la Asamblea general, salvo que tenga carácter universal, en los términos establecidos en estos Estatutos» por lo que deja abierta la posibilidad de que exista una Asamblea de todos los afiliados que, de acuerdo con los Estatutos, solo se daría para elegir a los miembros del Comité Ejecutivo. Existe cierta confusión que el sería conveniente aclarar. 
cuanto a la Comisión de Garantías, de acuerdo con el artículo 34 de los Estatutos, cinco miembros son elegidos mediante listas cerradas y voto secreto por la Asamblea General, dos por el Comité ejecutivo y dos mediante listas abiertas y voto secreto por el Consejo General ${ }^{75}$. La Comisión de régimen disciplinario de acuerdo con el artículo 92, estará compuesta por cinco miembros designados por el Comité ejecutivo. En segundo lugar, veamos los órganos territoriales: Ni los Comités Autonómicos (artículo 42), ni su Junta directiva (artículo 43), ni los Comités Provinciales o Insulares (artículo 46), ni los Comités locales (artículo 50), ni su Junta directiva (artículo 51), ni el Consejo de coordinación territorial (artículo 53) son elegidos por la militancia. En tercer y último lugar, vemos los órganos de deliberación democrática. Por una parte, están las Agrupaciones, en principio, de ámbito municipal y formadas por el conjunto de afiliados del municipio y que contará con una Junta directiva (artículos 33 a 35). Por otra, la Convención ciudadana, integrada, de acuerdo con el artículo 37 por los coordinadores de las Agrupaciones y por los miembros del Comité ejecutivo. A la vista de lo anterior, podemos afirmar que Ciudadanos es un partido muy burocratizado con un gran número de órganos y que otorga escaso protagonismo a la militancia para proveer sus puestos. Incluso, con los nuevos Estatutos desaparece la posibilidad de una Asamblea General de militantes presente en los anteriores Estatutos de 2007.

En cuanto a VOX, los miembros del Comité Ejecutivo Nacional, artículo 15, son elegidos por la Asamblea General de afiliados; los de Los Comités Ejecutivos Provinciales y de Ciudades Autónomas, artículo, 21, son elegidos igualmente por el conjunto de afiliados de cada provincia o ciudad autónoma. De acuerdo con el artículo 15 bis, El Comité de Gestión (CGe) y Comité de Acción Política están compuestos por cargos orgánicos. Los miembros del Consejo Político, lo serán por el Comité ejecutivo Nacional, según dispone el artículo 25. De acuerdo con el artículo 27, los miembros del Comité de Garantías, serán elegidos por mayoría simple de los asistentes a la Asamblea General, a propuesta del Comité Ejecutivo Nacional. El Comité electoral está formado por los mismos miembros que el Comité de Garantías, de acuerdo con el artículo 27 bis. Por último, los miembros de la Oficina Electoral Nacional serán designados, de acuerdo con el artículo 27 ter, por el Comité Ejecutivo Nacional.

\subsection{La participación de la militancia en la elaboración de documentos}

Importante es saber también qué papel juega la militancia en la confección de los documentos del partido, especialmente los estatutos y el programa electoral.

En el PSOE, de acuerdo con artículo 32, le corresponde al Comité Federal: «d. Elaborar y aprobar el programa electoral de ámbito estatal»y «g. Establecer las líneas fundamentales de la política electoral de acuerdo con las Resoluciones de sus congre-

75 En los Estatutos de 2007, de acuerdo con el artículo 34, los cinco miembros elegidos por la Asamblea General, lo eran en listas abiertas, lo que aseguraba un mayor pluralismo en la composición. 
sos y coordinar y ratificar los programas electorales de cada Federación de Nacionalidad con el programa federal». El artículo 26 otorga al Congreso Federal en su punto a. la definición de los principios y fijación los programas del Partido, estableciendo la línea política del mismo y fijando su estrategia y en su punto d. debatir y aprobar los Estatutos Federales del PSOE. El artículo 36 otorga a la Comisión Ejecutiva «La aprobación de todos los documentos políticos». No se prevé consultas a la militancia para la aprobación de los Estatutos ni de los programas electorales ni en el resto de documentos del partido en el artículo 53, ni entre los derechos de los militantes se reconoce de forma expresa su participación en la confección de los mismos. Es evidente, por tanto, la reticencia del aparato del partido a que se pronuncie la militancia en relación a estos extremos.

En cuanto al Partido Popular, el artículo 34 otorga a los Congresos del Partido, formados por compromisarios: b) aprobar o modificar la normativa reglamentaria y organizativa propias de su ámbito territorial sin poder alterar el conjunto de normas de rango superior, e) «debatir y adoptar cuantos documentos enriquezcan el pensamiento político del Partido Popular, definan su oferta electoral o afecten a la estrategia y gestión del Partido». A las Juntas Directivas les corresponden, dentro de su ámbito territorial de competencia: «a) Impulsar el cumplimiento de los programas, acuerdos y directrices emanadas de los Congresos del Partido...», b) recibir y debatir informes y proyectos sobre la organización, estrategia y programas del partido. A los Comités Ejecutivos les corresponde, de acuerdo con el artículo 40.1. b) Elaborar y adoptar cuantos informes y propuestas hayan de ser sometidas a su Congreso o Junta Directiva correspondiente», $\ll c)$ Definir la estrategia general del Partido y sus pronunciamientos políticos y programáticos, y d) Elaborar los programas de acción preelectoral y electoral. De la lectura de estos preceptos se deduce la existencia de una clara desconfianza del aparato del partido de dar la voz de forma directa y vinculante a las bases. Así, por ejemplo, el programa electoral está en manos exclusivas del núcleo duro del aparato del partido como es el Comité Ejecutivo. Por lo que la afirmación contenida en el Preámbulo de otorgar mayor protagonismo a los afiliados ${ }^{76}$ no se corresponde con el contenido de los Estatutos.

En Podemos, el artículo 14 otorga a la Asamblea Ciudadana, compuesta por todas las personas inscritas en el partido «Aprobar los programas electorales definitivos, tras un proceso de elaboración participativa». De igual manera, las Asambleas Ciudadanas Territoriales tienen, de acuerdo con el artículo 34, la competencia para «Aprobar los programas electorales definitivos (tras un proceso de elaboración participativa), debiendo estar sujetos a los principios generales aprobados por Asambleas de orden superior. Aquí se hace más presente el principio democrático, pero controlado, pues el poder de las estructuras superiores del partido se hace patente al exigirse

76 «La mejora en la participación de los afiliados en la vida interna ha sido otra de las premisas fundamentales que hemos tenido en cuenta a la hora de llevar a cabo la reforma estatutaria». 
que los programas en cuestión deben estar sujetos a los principios aprobados por Asambleas de ámbito superior.

Si acudimos a Ciudadanos, tenemos, por una parte, que entre los derechos que el artículo 18 (derechos en el contexto de una organización comparativa) se encuentran, entre otros, a) «a participar en las actividades del partido, contribuyendo activamente a la formación de la voluntad de sus órganos», b) «a presentar propuestas o proyectos, así como enmiendas, en el seno de la agrupación para su toma en consideración a los efectos de su remisión a los órganos superiores del partido», o c) «a participar en los procesos internos de consulta a los afiliados en orden a tomar conocimiento de su opinión respecto de cualquier asunto de interés cuando así lo decida el Comité ejecutivo, a propuesta del presidente del partido», derechos que, aunque con muchas cortapisas, garantizan cierta participación del militante en la elaboración de los documentos del partido ${ }^{77}$; por otra, el artículo 100.1. reconoce el derecho de los afiliados a «formular propuestas para su incorporación en los programas electorales» para, a continuación, en el punto 2, ir matizando a la baja dicha participación, al señalar que «los órganos del partido deberán recoger las propuestas para que, una vez seleccionadas aquellas que tengan relevancia e interés según los objetivos, fines e intereses del partido, así como su acomodo al ideario, programas, estrategia y otros documentos, sean elevadas a los órganos inmediatamente superiores en un proceso de sucesiva decantación y consolidación programática» para acabar estableciendo en su punto 3 , que será el Comité ejecutivo, a la vista de toda la documentación, el encargado de elaborar el programa electoral y, en su caso, el programa marco tener la obligación de incorporar determinadas propuestas aunque fueran presentadas por la mayoría de los afiliados y el Consejo general el competente para aprobarlos. A lo anterior hay que añadir que el gran número de órganos existentes con competencias para elaborar y aprobar documentos deja poco margen para que la militancia pueda, por si misma, aprobarlos. De los llamados órganos de deliberación democrática, sólo las Agrupaciones están formadas por la militancia y, paradójicamente, aunque se las califique de deliberativas, no se encuentra entre sus funciones deliberar sobre documentos, programas, cuestiones de actualidad, etc. En todo caso, será la Convención Ciudadana, calificada en el artículo 36 como «órgano de participación deliberativa de los afiliados» pero que no está formada por el conjunto de ellos sino por los coordinadores de las Agrupaciones, las que pueden deliberar sobre aquellos asuntos, y aquí entra en juego otra cortapisa, que el Comité ejecutivo decida plantear. En este contexto, cabe recordar que la Asamblea General, formada por compromisarios y no por la totalidad de militantes es la competente, de acuerdo con el artículo 60, para «aprobar los Esta-

77 Cortapisas como por ejemplo que en el punto b) solo se garantice que las propuestas, proyectos, etc., que se presenten serán tenidas en consideración a los efectos de su remisión a órganos superiores, independientemente de si el documento en cuestión es presentado por un militante o por una minoría o incluso por la mayoría de éstos; o el punto c) en el que claramente se especifica, por una parte, que los procesos internos de consulta sólo pueden producirse a propuesta del presidente del partido y, por otra, que los mismos no obligan ya que son solo a efectos de tomar conocimiento.

(C) UNED. Revista de Derecho Politico

N. ${ }^{\circ} 109$, septiembre-diciembre 2020, págs. 73-118 
tutos y sus modificaciones» o «debatir y, en su caso, aprobar resoluciones, acuerdos, programas o cualquier documento relativo a cuestiones ideológicas, políticas, programáticas, estratégicas o de cualquier otro tipo».

En cuanto a VOX, nada dicen los Estatutos de la participación de los militantes en la elaboración de documentos o programas. El artículo 7 al referirse a los derechos de los afiliados, de forma genérica habla en su punto 3 de "participar en las actividades del partido, en los órganos de gobierno y representación, y en la Asamblea General, de acuerdo con lo establecido en los Estatutos», sin que en los Estatutos desarrollen mecanismos que concreten este derecho. Si que es cierto que la Asamblea General, formada por la totalidad de afiliados, es la encargada de aprobar Estatutos y sus modificaciones, ponencias, normas, etc., sin embargo, nada se dice sobre quien elabora dichos documentos

\subsection{El papel de la militancia en la elaboración de las listas electorales}

Pasemos a analizar la confección de las listas electorales en los diferentes partidos políticos. Ya se ha hecho referencia a los cabezas de lista. Ahora cabe centrarse en el resto de miembros de las listas.

En el PSOE hay que acudir al documento «Elecciones 2019. Procedimiento para la elaboración de candidaturas ${ }^{78}$ que regula la confección de confección de listas para todo tipo de elecciones menos para las generales. De acuerdo con este documento las listas serán abiertas en municipios de más de 20.000 habitantes y cerradas en menos de 20.000 habitantes. Serán los los/as militantes y afiliados/as directos/as los que elegirán las propuestas de candidatos/as a los distintos procesos electorales a los que concurre el PSOE. En el caso del Parlamento Europeo, las propuestas serán elevadas a la Comisión Ejecutiva Federal que será el que hará la propuesta de candidatura será trasladada a la Comisión Federal de Listas, que emitirá su dictamen previo a la ratificación definitiva del Comité Federal.

Para las elecciones autonómicas, recibidas las propuestas, las comisiones ejecutivas provinciales o insulares elaborarán una propuesta de lista que elevarán, a su vez, a cada comisión regional o de nacionalidad de listas que «emitirá un dictamen formulando su propuesta» que será presentado al comité regional o de nacionalidad que lo aceptará o rechazará. Los proyectos de lista aprobados por los comités regionales o de nacionalidad serán remitidos a la Comisión Federal de Listas que los ratificará o modificará. Por último, el dictamen de la Comisión Federal de Listas se someterá a la aprobación definitiva por parte del Comité Federal.

Para elecciones en municipios de más de 50.000 habitantes, será la Comisión Ejecutiva Municipal la que elevará una propuesta a la Comisión Ejecutiva provincial o insular si la agrupación municipal está constituida en gran ciudad; en el resto de municipios, teniendo en cuenta las propuestas realizadas, la Comisión Ejecutiva Pro-

78 https://www.psoe.es/media-content/2015/04/Elaboraci\%C3\%B3n-de-candidaturas.pdf 
vincial o insular remitirá a la comisión provincial, o insular, de listas una lista ordenada, así como los resultados de las asambleas La comisión provincial o insular de listas «planteará su dictamen» ante el Comité Provincial que lo aprobará o rechazará. A su vez, este órgano remitirá su decisión a la Comisión Ejecutiva Regional o de nacionalidad Comisión Ejecutiva regional o de nacionalidad. Ésta «remitirá su informe y recomendaciones» a la Comisión Federal de Listas» que emitirá su «dictamen» previo a la aprobación definitiva por parte del Comité Federal de las candidaturas. Para el resto de municipios se sigue un procedimiento similar solo que en este caso la lista definitiva es aprobada definitivamente por la Comisión Federal de Listas.

En este documento no aparece regulado la confección de listas para el Congreso y el Senado. En la Normativa Reguladora de los Cargos Públicos ${ }^{79}$ se regulaba este extremo. Así se establecía que se propondrán candidaturas completas para integrar una lista para los procesos electorales legislativos a las Cortes Generales (Congreso de los Diputados y Senado. La elaboración de propuestas por las Agrupaciones Municipales o de Distrito de candidatos al Congreso de los Diputados, al Senado se realizará por medio de un sistema de listas abiertas. Para la elaboración de las listas a las Cortes Generales, de acuerdo con el artículo 57, la Comisión Ejecutiva Provincial o en su defecto la Comisión Ejecutiva Regional o de Nacionalidad, a la vista de las propuestas recibidas, elaborará una candidatura que será sometida a la aprobación del Comité Provincial, Regional o de Nacionalidad según corresponda, tras dictamen de la Comisión Federal, corresponde la aprobación definitiva, de acuerdo con el artículo 59 al Comité Federal.

Por lo que respecta al Partido Popular, de la lectura de los preceptos de sus Estatutos dedicados a esta cuestión se deduce el nulo o escaso papel desempeñado por las bases. Más bien queda patente el férreo control del aparato para este cometido. El artículo 52.1 señala que son los Comités Electorales los órganos competentes para todos los asuntos relativos a la confección de las candidaturas. El punto 4 del mismo precepto señala que «podrán solicitar asesoramiento de aquellos cargos directivos del Partido que estimen conveniente. Asimismo, podrán promover la participación de los distintos órganos territoriales del Partido en la confección de las diferentes candidaturas». El artículo 52.1. establece que es el Comité Electoral Nacional el que «elabora y aprueba la candidatura del Partido al Parlamento Europeo, aprueba las candidaturas a presentar en las elecciones legislativas y autonómicas y en las municipales de capitales de provincia, designa a los candidatos a las presidencias de los gobiernos de las Comunidades Autónomas, presidencias de las Diputaciones, alcaldías de las capitales de provincias, y ratifica los candidatos a Senadores por las Comunidades Electorales Regionales» aunque "podrán delegar sus competencias en los Comités Regionales, previa conformidad del Presidente Nacional. El punto 2 establece, por su parte que «el Comité Electoral Regional elabora y propone las candidaturas al Órgano legislativo de la Comunidad Autónoma, designa a los candidatos a Senador

79 http://web.psoe.es/source-media/000000212000/000000212157.pdf 
en representación de éstas y aprueba todas las candidaturas municipales de localidades de más de 20.000 habitantes» Por su parte, el punto 3 señala que «el Comité Electoral Provincial elabora y propone la candidatura en las elecciones legislativas y la candidatura municipal de la capital de provincia; y aprueba todas las candidaturas de localidades que no superan los 20.000 habitantes. El punto 4 establece que «el Comité Electoral local elabora y propone la candidatura municipal». En cuanto a los archipiélagos, el punto 5 advierte que «se estará a lo que establezcan sus Reglamentos Regionales en orden a las competencias de los Comités Electorales Insulares, sin perjuicio de lo dispuesto en el artículo 51.5. que obliga a que cada isla tenga su propio Comité Electoral, con las competencias propias de un comité electoral provincial.

En lo que respecta a Podemos, el artículo 14 establece como competencia de la Asamblea ciudadana «elaborar las listas electorales para optar a cargos públicos para las instituciones de representación de carácter general, mediante la celebración de elecciones primarias y abiertas a todas las personas afiliadas a Podemos. El artículo 34 confiere a las Asambleas Autonómicas la aprobación de las listas electorales en el ámbito autonómico y el artículo 46 hace lo propio con la Asambleas Ciudadanas Municipales en el ámbito local.

En cuanto a Ciudadanos, si bien los cabezas de lista son elegidos mediante primarias, lo cierto es que la militancia no tiene voz a la hora de elegir al resto de miembros de las listas electorales pues, de acuerdo con el artículo 101.2. cada uno de los correspondientes comités autonómicos elevará un informe al Comité Ejecutivo, que decidirá de manera definitiva.

En cuanto a Vox, de acuerdo con el artículo 24, y como se ha señalado anteriormente, es el Comité Ejecutivo Nacional el que aprueba las candidaturas a las diferentes elecciones tras las oportunas consultas o propuestas de los Comités Ejecutivos Provinciales y Comités de Ciudad Autónoma.

Salvo Podemos, el resto de partidos deja en manos del aparato del partido la elaboración de las listas electorales definitivas. Los mecanismos de democracia interna de los partidos deberían regular los mecanismos la elección de los candidatos eliminando o, al menos, atemperando, lo que DUVERGER calificaba de elementos autocráticos en la elección de los representantes ${ }^{80}$. Los candidatos deberían ser elegidos de abajo a arriba y no al revés, como sucede actualmente. De paso, se terminaría con otra patología en su designación: los cuneros.

\subsection{Otros mecanismos de democracia directa y de democracia participativa}

En cuanto al PSOE, por una parte, tenemos el derecho de iniciativa recogido en el artículo $9.2 \mathrm{~m}$. que se ejercerá ante la respectiva Comisión Ejecutiva o ante los máximos órganos del Partido entre Congresos a nivel local, provincial, autonómico, de nacionalidad y federal. Las iniciativas que cuenten con el apoyo de un mínimo del

80 DUVERGER, M., Instituciones políticas y Derecho constitucional, Ariel, 1970, p. 128. 
$20 \%$ de las firmas de los militantes del ámbito territorial respectivo del órgano al que se dirija la iniciativa, serán de tratamiento obligado para éste. El artículo 52 regula la participación de los militantes en las conferencias para cuestiones políticas y sectoriales de especial trascendencia; ahora bien, órgano convocante de las Conferencias será el Comité Federal. Por otra parte, segunda restricción a la participación de la militancia, de acuerdo con el artículo 488 del Reglamento Federal de Desarrollo de los Estatutos, La mitad de los/s participantes en las conferencias se elegirán mediante el voto individual, directo y secreto de los/s militantes del PSOE del correspondiente ámbito territorial y que tengan plenos derechos políticos y la otra mitad la designará la Comisión Ejecutiva del ámbito territorial que corresponda. Sus resoluciones tendrán un carácter deliberativo e instrumental. Todo un ejemplo de control por parte del aparato.

El artículo 53.1 de los Estatutos regula las consultas a la militancia: «Las Comisiones Ejecutivas de nacionalidad, regionales, insulares, provinciales o municipales podrán convocar consultas a la militancia sobre aquellos asuntos de especial trascendencia que se determinen reglamentariamente y que afecten a su ámbito territorial de actuación. La celebración de estas consultas deberá ser previamente autorizada por la Comisión ejecutiva de ámbito superior a 1a proponente». De entrada, es un ejercicio de democracia que se permita consultar a la militancia sobre aquellas cuestiones que la Comisión Ejecutiva correspondiente considere oportunas. Sin embargo, es un ejercicio de democracia vigilada o controlada, toda vez que tal consulta «deberá ser autorizada por la Comisión ejecutiva de ámbito superior a la proponente». Las Comisiones ejecutivas cuanto más bajas en el escalafón, más cercanas a la militancia y, a contrario sensu, cuanto más arriba en la estructura del partido más integradas en su aparato. La exigencia de que la consulta ha de ser aprobada por una Ejecutiva que es más aparato que la proponente, muestra cierta desconfianza hacia este mecanismo de democracia directa. Estas consultas, de acuerdo con el Reglamento Federal de Desarrollo de los Estatutos ${ }^{81}$, artículo 478, tendrán con carácter general el carácter de vinculantes. De ahí la trascendencia del punto 2 del artículo 53, que señala que «en todo caso, será obligatoria la consulta a la militancia, al nivel territorial que corresponda sobre los acuerdos de Gobierno en los que forme parte el PSOE o sobre el sentido del voto en sesiones de investidura que supongan facilitar el gobierno a otro partido político». El artículo 479 del Reglamento Federal de Desarrollo de los Estatutos añade como obligatoria la consulta "para decidir, en su caso, la revocación de los/as Secretarios/as Generales en los términos previstos en el artículo 5 bis.1.a) de los Estatutos Federales». Nada hay que objetar si se trata de consultas sobre cuestiones internas. El problema aparece, en mi opinión, cuando se consulta a la militancia sobre cuestiones de gobierno tales como llegar a acuerdos para formar gobiernos de coalición o pactos de legislatura, etc. En España realmente no hay partidos de militantes sino partidos de electores y como advierte LINZ, «el problema es que el demos del partido

${ }^{81}$ https://www.psoe.es/media-content/2018/02/ReglamentoCF17022018.pdf 
y el demos de los ciudadanos que eligen a los miembros del Parlamento son dos demoi diferentes ${ }^{82}$. En el PSOE, los militantes sumarán unos 180.000 mientras que en los últimos comicios de 10 de noviembre de 2019 esta formación superó los seis millones y medio de votos. La duda es si la militancia es reflejo de los electores, es una «muestra representativa» de la parte del electorado que votó las listas del partido en cuestión. ¿Puede una minoría, exigua, decidir sobre cuestiones de la política general? Ello es derogar de facto el principio de representación y el ya maltrecho mandato representativo en crisis, como advierte, entre otros, TORRES DEL MORAL, desde hace tiempo $^{83}$, introduciendo de forma subrepticia un mandato imperativo ahora ya no en favor del partido sino de un grupo de personas, la militancia, que no goza de ningún reconocimiento constitucional ni puede esgrimir título habilitante alguno para asumir tal función. Es cierto que en un sistema como el nuestro de listas cerradas y bloqueadas es una fictio que el electorado vote a los candidatos y no al partido. Como advierte CHUECA, en el Estado democrático la elección «expresa la confianza del elector en unos sujetos colectivos constitucionalmente reconocidos y respaldados en sus funciones: los partidos políticos» ${ }^{84}$ pero no es menos cierto que la militancia no puede arrogarse la representación de los votantes pudiendo, no obstante provocar una grave crisis de gobernabilidad. Nuestro Tribunal Constitucional está anclado en la teoría clásica del mandato representativo que casa mal con la realidad política. Existe un divorcio entre realidad política y realidad jurídica y, como afirma DE VEGA, «en el supuesto de confrontación entre diputado y partido es evidente que la lógica de la democracia partidista y del principio de proporcionalidad, tienen que ceder por obligación a la lógica del principio clásico de representación, por ser el único constitucionalmente regulado». ${ }^{85}$ Son representantes quienes resultan designados directamente por elección popular, de tal manera que hacen efectivo el derecho que corresponde a los ciudadanos a la participación política, de ahí que derecho de sufragio activo esté unido indefectiblemente al derecho de sufragio pasivo. La elección sólo puede recaer sobre personas determinadas y no sobre partidos o asociaciones que proponen las candidaturas al electorado. Los representantes no lo son de sus votantes concretos sino de todo el cuerpo electoral ya que la representación, como ha subrayado la STC 10/1983, de 21 de febrero, es siempre del cuerpo electoral y nunca del autor de la propuesta. El Tribunal Constitucional proscribe en dicha sentencia cualquier tipo de mandato imperativo proveniente del partido dejando la puerta abierta a alguna fórmula de este tipo proveniente, en todo caso, del electorado: «no es teóricamente inimaginable un sistema de democracia mediata o indirecta en la que los represen-

82 LINZ, J.J., «Conclusiones. Los partidos políticos..., op. cit. p. 298.

83 TORRES DEL MORAL, A., «Crisis del mandato representativo en el Estado de Partidos», Revista de Derecho Político, no 14, 1982, pp. 7 y ss.

84 Chueca RODRÍGUEZ, R., «La representación como posibilidad en el Estado de Partidos», Revista de Derecho Político, núm. 27-28, 1988, p. 42

85 DE VEGA, P., «Significado constitucional de la representación política», Revista de Estudios Políticos, núm. 44, 1985, p. 41. 
tantes estén vinculados al mandato imperativo de los representados». Al representante político, la legitimidad le viene dada por las urnas, la cuestión es ¿qué legitimidad puede esgrimir la militancia para decidir sobre asuntos de interés general que van más allá de la vida intrapartidista?. Ninguna. Algún resquicio podemos encontrar como acabamos de ver, en la jurisprudencia del Tribunal Constitucional para señalar a los electores como titulares de una legitimidad de ejercicio. En la citada sentencia de la Audiencia Nacional de 31/2014, de 7 de julio, relativa al intento de rodear el Parlament de Catalunya, este tribunal otorgaba una legitimidad de origen a los manifestantes $^{86}$, a los que poco menos que identificaba con el electorado. Considerando implícitamente que los diputados catalanes habían perdido, o estaban a punto de perder, su legitimidad de origen si votaban a favor de las medidas económicas propuestas por el Govern de Catalunya (es decir, quedaban deslegitimados por su ejercicio) y que los manifestantes estaban imbuidos de la potestad de desposeer de la legitimidad de origen a los cargos representativos. Así afirma que: «Quienes protestaban no querían las restricciones económicas de las prestaciones y de los servicios públicos; y quienes adoptaban tales decisiones ya no les representaban. Mensajes directamente relacionados con la Constitución social (...) y con la Constitución democrática, en la medida que requerían a los representantes políticos, a los diputados, para que respondieran a los intereses generales, a los de la mayoría de la sociedad, y cuestionaban la legitimidad de ejercicio de su propia representación» para seguir diciendo que «desde esa perspectiva conviene hacer notar que la protesta suponía la defensa de la Constitución y de sus contenidos básicos» y concluir que los manifestantes estaban en posesión de una especie de mandato imperativo con las siguientes palabras: «en alguna medida, la protesta se dirigía al corazón del concepto y del modo de ejercicio de la democracia en nuestros sistemas (...)La protesta que ejercían moldeaba algo parecido a lo que, bien es cierto que en pocos momentos de la historia de las sociedades, se ha conocido como acción de revocatoria de mandatos, una forma de intervención democrática directa para el control de la representación», todo y reconocer que nuestra Constitución prohíbe el mandato imperativo. Los participantes en el piquete que se «confrontaba con los diputados del Parlament de Catalunya» «se erigían en portavoces de un sector de la sociedad». Ante ello cabe preguntarse quién y a través de qué mecanismos les había sido atribuida tal facultad. El argumento de la Audiencia es del todo erróneo y nos llevaría a reconocer la existencia de una confrontación entre unos representantes de parte de la sociedad anónimos, sin poder esgrimir título habilitante de esa repre-

86 Crítico con estos movimientos se mostraba G. Peces-Barba, «Los indignados y la democracia», El País, 13 de septiembre de 2011. Que afirma «los jóvenes indignados son en general personas de buena fe, que denuncian problemas reales, pero que tienen tan alta opinión de sí mismos que no respetan el pluralismo ni otras opiniones diferentes, y que, con una soberbia desmesurada, creen que pueden partir de cero yreinventar una democracia asamblearia, sin partidos ni elecciones por sufragio universal» concluyendo que «no creo que con esas premisas tengan ni adhesiones ni futuro. Además el peligro del fascismo, al menos en las formas, está también presente». 
sentación y unos representantes con nombres y apellidos de esa misma sociedad, elegidos unos meses antes en las urnas. No puede la Audiencia poner en un plano de igualdad a unos y otros. ¿Dónde reside la legitimidad de origen de los primeros? En todo caso, serían los legítimos representantes o portavoces de las entidades convocantes de la manifestación los que podrían hablar en nombre de éstas y sólo de éstas, no en nombre de la sociedad. La legitimidad o bondad de los objetivos perseguidos en la manifestación, compartir sus ideas o reivindicaciones, por muy mayoritario que sea ese sentimiento en el seno de la sociedad, no es título suficiente para arrogarse unos participantes en ella la representación de una parte de la sociedad $^{87}$.

En todos estos tipos de procesos no se tiene en cuenta para nada la opinión de los cargos representativos que son los que han sido elegidos por el electorado y que son los que dan apoyo en sede parlamentaria a ese gobierno. La militancia no puede esgrimir título habilitante alguno para imponer su voluntad en cuestiones de gobierno. ¿qué sucedería en caso de discrepancia entre lo que desea la militancia y lo que desean los miembros de un grupo parlamentario? Por otra parte, no deja de llamar la atención que se intenten estas fórmulas y, en cambio, ningún partido, especialmente cuando está en el poder, promueva consultas a la ciudadanía en cuestiones de vital importancia tales como reformas de la ley del aborto o la introducción de la pena privativa de libertad permanente revisable.

Habrá que acudir al Título Tercero de los Estatutos para ver en qué consiste la participación de militantes y ciudadanos en el seno del Partido Popular y concluir que es más una cuestión cosmética que de fondo. El artículo 59 configura al Partido Popular «como un partido abierto a la participación de todos los ciudadanos, afiliados o no (...) a través de los cauces previstos en el presente título». Primera restricción: la participación será exclusivamente a través de los mecanismos ideados por el partido. Segunda restricción: el artículo 60 establece la figura del «responsable de participación», que fácilmente puede convertirse en una especie de comisario político, que a modo de coordinador es designado por los Comités ejecutivos en sus diferentes ámbitos. El artículo 61 establece los instrumentos de participación: oficina parlamentaria, foros, Comisiones de Estudio, plataformas de Participación virtuales, perfiles oficiales (portales) del Partido Popular en las principales redes sociales, Servicio de Atención al Ciudadano. Todos estos mecanismos verdaderamente no son de participación efectiva de los ciudadanos o afiliados en la medida en que son más bien instrumentos mediante los cuales éstos pueden expresar su opinión, pero no participar en la toma de decisiones, No se dice nada, del resultado de dicha participación ni del valor de las aportaciones que de ellos pueda surgir.

87 Al respecto vide CATALA i BAS, A.H., «Asalto al Parlament de Catalunya: Confrontación real de derechos y supuesta de legitimidades», Revista general de derecho público comparado, $\mathrm{N}^{\circ}$. $19,2016$. 
Si analizamos los Estatutos de Podemos vemos que la participación ciudadana se encauza principalmente a través de los llamados Círculos, que pueden ser territoriales o sectoriales. El artículo 57 señala que el Círculo o el Espacio Municipal Unificado «es la herramienta con la que Podemos promueve la participación, el debate y la relación activa de la organización con la sociedad». Por su parte, el artículo 58 señala que «podrán llevar a cabo cuantas actividades decidan dentro del marco legal general, el Código Ético y los Estatutos de Podemos. Para garantizar el acomodo legal y estatutario, deberán coordinarse con la Secretaría General de Organización de su ámbito territorial» ${ }^{88}$. La cuestión es saber el papel que realmente desempeñan esos círculos en la toma de decisiones del Partido. Sin duda limitado. Son un foro de debate que, incluso, pueden gozar, de acuerdo con el artículo 58, de personalidad jurídica pero las decisiones se toman en las correspondientes Asambleas. Ello no obstante, no tiene por qué ser, de entrada, criticable pues los Círculos no pueden funcionar como unos órganos ejecutivos paralelos. Su función, es otra, la de hacer realidad la democracia participativa, entrando en contacto con la sociedad civil y hacer llegar al partido las cuestiones que en ella se susciten. Así se desprende, por ejemplo, de los artículos 62 y 65. Cierto es que parecen haber perdido peso específico en el partido. Como ejemplo podemos citar el artículo 51.5 de los anteriores Estatutos que señalaba que «e1 Consejo Ciudadano, como parte de su proceso deliberativo, deberá consultar preceptivamente a los Círculos Sectoriales en aquellas materias que sean de su competencia, dada su especialización». En el artículo 66 de los nuevos Estatutos queda diluido a «convocar debates en los Consejos Ciudadanos, de acuerdo con los procedimientos aprobados» aunque también hay que advertir que ahora, y de acuerdo con el artículo 19, forman parte del Consejo Ciudadano Estatal cuatro miembros en representación de los círculos, circunstancia no contemplada en los anteriores (artículo 22 de los anteriores estatutos). Cabe tener presente el artículo 31 de los nuevos estatutos de la formación, intitulado De la subsidiaridad, que reafirma lo aquí dicho: «sin perjuicio de la coordinación de la estrategia política y del principio de jerarquía normativa de los ámbitos territoriales superiores, Podemos actuará con un principio de subsidiariedad siendo los órganos territorialmente inferiores los privilegiados para establecer criterios propios en lo que respecta a la acción política dentro de su propio territorio». Se introducen, por tanto, correctivos al principio de subsidiariedad. Esta tónica se repite en el segundo párrafo de este precepto: «La decisión de la Asamblea Ciudadana

88 Más contundentes en el control de los Círculos se mostraban los primeros Estatutos. Estos, si bien afirmaban en el artículo 53.1. que los Círculos «serán soberanos en su toma de decisiones siempre que, no contravengan y sean coherentes con las decisiones del partido», quedando obligados, de acuerdo al artículo 53.5. a "participar e impulsar los distintos movimientos que (...) estén en sintonía con los planteamientos de PODEMOS», es decir, con las decisiones de sus órganos directivos, por lo que existía la clara posibilidad de un control sobre los Círculos por parte de la cúpula del partido. Dejaba claro el artículo 55.2. que «si una iniciativa de un Circulo afecta en algún sentido a la imagen o desempeño de PODEMOS en el ámbito territorial de una Asamblea y Consejo Ciudadano, éstos serán competentes para evaluar la misma y autorizar o desautorizar su desarrollo».

(C) UNED. Revista de Derecho Politico

N. ${ }^{\circ} 109$, septiembre-diciembre 2020, págs. 73-118 
territorial (de comunidad autónoma, de ciudad autónoma o de circunscripción exterior) que no afecte a competencias estatales o a la relación entre el nivel estatal y el territorial correspondiente serán irrevocables por Asambleas Ciudadanas de ámbito superior. La redacción del precepto es calculadamente confusa ¿qué quiere decirse exactamente con «relación entre el nivel estatal y el nivel territorial correspondiente»?. Lo abierto de la frase permite la intervención del órgano superior que es quien decide, en todo caso, si queda afectada dicha relación, sin que la Asamblea inferior pueda defenderse de esta actuación.

A pesar de que artículo 18 de los Estatutos de Ciudadanos lleva por título «derechos en el contexto de una organización participativa» y que el Capítulo 2 del Título III lleva por título órganos de deliberación democrática, los Estatutos no prevén auténticos mecanismos de participación de las bases en la toma de decisiones, más allá de ser consultados cuando el aparato del partido así lo considere oportuno sin que el resultado de dicha consulta obligue a éste. No prevén los Estatutos mecanismos de participación de la militancia como las consultas a las que hemos hecho referencia supra.

Los Estatutos de VOX no concretan mecanismos de participación de la militancia.

\section{LA LIBERTAD DE EXPRESIÓN DE LOS MILITANTES ${ }^{89}$}

Tradicionalmente los partidos han expresado sus opiniones y se han posicionado sobre cuestiones de interés general, a través de sus dirigentes. Raramente el militante de base tenía la oportunidad de acceder a los medios de comunicación para expresar sus opiniones. Hoy en día, merced a las nuevas tecnologías esto ha cambiado. El militante anónimo tiene la oportunidad de dar a conocer su opinión fácilmente a través de las redes sociales, El partido ya no tiene una única voz, sino que se multiplican las voces lo que si bien por una parte es un ejercicio de democracia pues alimenta y amplía el debate político permitiendo que todos expresen su opinión, el partido pierde el control sobre el mensaje que quiere transmitir.

Todos los partidos reconocen la libertad de expresión como uno de los derechos de los afiliados. Sin embargo, intentan controlarla de forma más o menos subrepticia con un sinfín de límites como honor e imagen del partido, lealtad y responsabilidad, proyecto político y un largo etcétera del que vamos a ver unos ejemplos.

Si consultamos los Estatutos Federales del PSOE, entre los derechos de los afiliados, artículo 9, aparece recogido en el punto 2.c) «el derecho a formar parte de los grupos socialistas que se formen o existan y a la libre expresión de ideas o iniciativas

89 Al respecto vide CATALA i BAS, A.H., «La lealtad como límite a la libertad de expresión de los militantes de los partidos políticos.: Malos tiempos para los versos libres» en Una vida dedicada al Parlamento: Estudios en homenaje a Lluís Aguiló i Lúcia, Corts valencianes, 2019, págs. 109-124. 
en su seno» y en el punto 2.d) «el derecho de discusión y crítica sobre posiciones políticas propias y ajenas mediante la libre expresión oral o escrita y a su libre comunicación dentro del partido». Ello no obstante, el siguiente punto, el punto e), matiza «a la baja» este derecho pues recoge «el derecho a realizar manifestaciones públicas, juicios de valor y expresiones, de forma libre, leal y responsable, dentro de los límites del respeto a la dignidad de las personas, así como a las resoluciones y acuerdos democráticamente acordados por los órganos del Partido en el marco de sus competencias estatutarias». Se introducen, así, introduce una serie de límites: lealtad, responsabilidad, respeto a la dignidad de las personas y a las resoluciones y acuerdos adoptados democráticamente por el partido, muchos de los, conceptos abiertos, ambiguos y metajurídicos, que dejan un amplio margen al partido para restringir la libertad de expresión de los militantes. Así, por ejemplo, la lealtad, que es sinónimo de fidelidad; en este caso, se supone, que al partido. Este concepto ético, permite calificar de desleal, infiel o traidor a todo aquel que se manifestarse contra las posturas, acuerdos, compromisos adoptados por el partido. De hecho, el tercer límite que se introduce, respeto a las resoluciones y acuerdos adoptados democráticamente por el partido, refuerza estas ideas. Es decir, no puede un militante criticar lo acordado por la mayoría. Así se silencia a la minoría. Si esto es así, las voces disidentes que no acataron o respetaron que se alzaron contra el acuerdo de la Junta Gestora de abstenerse en la investidura de Mariano Rajoy, en octubre de 2016, incumplieron ese precepto, opción duramente criticada por el propio Pedro Sánchez.

Esta idea, la de controlar la opinión del disidente, en mi opinión, aparece reforzada en diversos preceptos de los Estatutos del PSOE. Así el artículo 3.5 habla de que la unidad del Partido descansa esencialmente en la unidad de pensamiento fundamental; el artículo 4.2. permite las corrientes de opinión siempre «dentro del respeto a los Estatutos, Programa y decisiones de los órganos de gobierno»; el punto 5 del mismo precepto exige que los afiliados y afiliadas que participan en los trabajos de una corriente de opinión cuidarán que no trascienda al exterior de la Organización expresiones contrarias a las resoluciones de los congresos y a las de los demás órganos de dirección» (afirmación un tanto sorprendente pues casa mal con las invocaciones a la transparencia y al pluralismo); el artículo 7 sanciona al afiliado que «falte al programa o los acuerdos o resoluciones del Partido, exprese públicamente sus opiniones en términos irresponsables o con deslealtad al Partido o a sus afiliados y afiliadas, cometa actos de indisciplina, injurie o calumnie a alguna persona que pertenezca al partido»; y el artículo 9 establece como «deber la defensa de las resoluciones y estatutos aprobados por los Congresos, así como los acuerdos legítimamente emanados de sus órganos de dirección».

En los Estatutos del Partido Popular encontramos entre los derechos de los militantes, artículo 7, el de opinar y participar en el debate interno a través de las herramientas puestas en marcha para tal fin. Entre los deberes, artículo 8, se encuentran el de respetar pública y privadamente el honor y la imagen del Partido, de sus órganos y de todos sus afiliados, Entre otra causas, se pierde la condición de afiliado, artículo 
11, «por manifestación pública de discrepancia grave con la ideología principios o fines del Partido, realizada en actos de propaganda, reuniones públicas o a través de cualquier medio de comunicación escrito o audiovisual o de cualquier medio de difusión que garantice la publicidad del hecho. El artículo 16 (infracciones graves) considera tales, entre otras: d) «Por manifiesta deslealtad al Partido, a sus órganos de Gobierno y representación», f) toda manifestación o declaración hecha con publicidad que incite al incumplimiento o descalificación de las decisiones válidas y democráticamente adoptadas por los órganos de gobierno y representación del Partido, o de los Grupos Institucionales del mismo; Por su parte, y entre las infracciones, encontramos en el punto 17 entre otras: a) «Propagar, por cualquier medio, noticias que desprestigien al partido, sean descalificatorias del mismo o de cualquiera de sus órganos de Gobierno, representación o de los Grupos institucionales; b) Realizar declaraciones y manifestaciones públicas en nombre del Partido que comprometan políticamente al mismo sin contar con la autorización expresa del Presidente del Comité Ejecutivo que corresponda en sus diferentes ámbitos; e) «Cualquier manifestación pública oral o escrita en los medios de comunicación que suponga descrédito, menosprecio o descalificación de cualquier afiliado al partido».

El partido desea tener controlada la opinión de los afiliados con toda una batería de obligaciones o responsabilidades. Ésta, como señala el punto g) del artículo 7, merecerá el amparo del partido únicamente si se expresa en el debate interno y a través de los canales diseñados y controlados por el partido y siempre que se lleve a cabo dentro de los cauces que se derivan preceptos como los transcritos que contienen un sin fin de límites expresados en términos abiertos o indeterminados que permiten un amplio margen de maniobra al aparato del partido a la hora de controlar o acallar las opiniones disidentes: «Honor e imagen del partido, de sus órganos y de los afiliados», «principios, fines y programas», «principios ideológicos», «orden constitucional», «ideología, principios y fines del partido», «manifiesta deslealtad», «desprestigio del partido», «comprometer al partido», «descrédito, menosprecio o descalificación...».

Por lo que respecta a la formación política Podemos, lo primero que llama la atención es que en los actuales Estatutos desaparece como derecho de los afiliados (artículo 7), el derecho a expresar libremente sus opiniones que sí se recogía de forma expresa el artículo 6, punto d, de los antiguos Estatutos: «Expresar libremente sus opiniones en los debates internos», aunque, como parece ser tónica general, el libre ejercicio de este derecho quedaba circunscrito intra partido, en los debates internos, pero no extra partido, es decir, en los debates que puedan mantenerse ante la opinión pública. Este partido no va a ser una excepción en el intento de limitar la libertad de expresión de sus afiliados. De esta manera, encontramos, en cuanto a los deberes de las personas afiliadas el de «respetar lo dispuesto en los presentes Estatutos, los documentos aprobados por la Asamblea Ciudadana, los reglamentos que los desarrollan, el Plan de Cumplimiento Normativo, la normativa de los órganos y círculos a los que pertenece y los protocolos de aplicación de las funciones que se lleven a cabo por las diferentes secretarías, áreas y equipos (artículo 8.3.), acatar, cumplir y defender los 
acuerdos válidamente adoptados por los órganos del partido (artículo 8.4.). En cuanto a las infracciones, por ejemplo, el punto 1 del artículo 75 establece como tal en su punto a. «las manifestaciones públicas situadas fuera del debate ideológico que, teniendo por objeto, desacreditar a las personas o menospreciarlas, causen daños a los miembros de los órganos, grupos o asambleas, o a la convivencia de las personas dentro del partido», y en su punto c. «la actuación pública que, sin perjuicio de la libertad de crítica, pretenda desacreditar de forma destructiva las decisiones colegiadas de los órganos o de la Asamblea Ciudadana que los ha elegido». El punto 2 de dicho precepto establece también como tales, entre otras, como infracciones graves, entre otras c. "propagar noticias falsas o manipuladas que desprestigien a Podemos, sean descalificatorias de la organización o de sus órganos; f. «cualquier utilización o uso indebido de la documentación datos y/o información que se tengan, o a los que se haya tenido acceso por razón del cargo o función desempeñada en los diferentes órganos de Podemos; h.» transmitir o filtrar información interna que comprometa la actuación de los órganos, la acción política de la organización o la buena imagen de las personas que las representan; i. «realizar actuaciones o declaraciones públicas en nombre de los órganos de Podemos sin ser portavoz de los mismos ni contar con su autorización expresa». El punto 3 del citado precepto señala, entre otras j. «la indisciplina grave, expresa y reiterada, en relación con las legítimas decisiones de los órganos competentes de Podemos».

Si acudimos a los Estatutos de Ciudadanos, esta formación reconoce la libertad de expresión de sus militantes, pero la rodea de una serie de contramedidas que intentan tener bajo control su ejercicio. El punto b) de del artículo 17 reconoce el derecho a la libertad de expresión de los afiliados, pero únicamente «en el ámbito interno del partido». Los Estatutos están repletos de principio a fin de mandatos genéricos, abiertos, que dejan un amplio margen de actuación del aparato del partido contra el disidente. Así, y por poner unos ejemplos, el artículo 9, referido al principio de unidad de acción, exige que se actúe «con lealtad, sentido del deber y disciplina», de tal manera que adoptada una decisión haya «un comportamiento de diligente cumplimiento y ejecución de lo decidido», sin posibilidad de disidencia; el artículo 11, dedicado a la adquisición de la condición de afiliado pero que contiene una larga lista de deberes que se suman a los establecidos en el artículo 23, exige a los afiliados «un deber de lealtad al partido y a sus dirigentes, sin incurrir en ningún acto de denigración, así como de respeto a los afiliados». El citado artículo 23 exige a los afiliados «acatar, cumplir, así como ejecutar los acuerdos, resoluciones y todas las decisiones adoptadas por los órganos del partido», no siendo posible la disidencia; «respetar públicamente la imagen del partido, de sus órganos y de todos sus afiliados, así como la dignidad de sus miembros»; guardar reserva de las deliberaciones de los órganos del partido en los que participe o sea miembro, así como de cualquier otra información de la que tuviera conocimiento y cuya reserva hubiese sido decidida por los órganos competentes del partido. Por último, entre las infracciones muy graves, artículo 116 el Estatuto prevé «efectuar manifestaciones públicas que menoscaben el 
buen nombre del partido o de sus afiliados» o «la manifiesta deslealtad al partido y a sus órganos», «incitar, con publicidad, al incumplimiento de acuerdos y decisiones», «realizar manifestaciones públicas desleales o contrarias a los intereses del partido, que comprometan gravemente su consideración ante la opinión pública», «realizar declaraciones o manifestaciones públicas en nombre del partido sin contar con la autorización del órgano competente, cuando redunde en un daño relevante a su consideración ante la opinión pública».

Vox no es una excepción a la línea marcada por los anteriores partidos, aunque cabe señalar que es menos prolijo en introducir elementos que limiten este derecho. Sus estatutos reconocen este derecho sólo en el ámbito interno y únicamente para aquellas reuniones en las que el militante estuviera convocado. De acuerdo con el artículo 8 se está obligado a «acatar y cumplir los acuerdos válidamente adoptados por los órganos directivos del partido» y «mantener la debida disciplina y buenas formas en todos los actos del partido» considerándose infracción, entre otras, «las manifestaciones verbales o escritas por cualquier medio que dañen la imagen pública del partido o de cualquiera de sus órganos colegiados, de sus miembros y afiliados, sin perjuicio del derecho de todo afiliado a ejercer la crítica o a emitir opinión sobre las políticas y líneas estratégicas adoptadas por los órganos competentes».

De lo expuesto cabe deducir de forma clara que los partidos políticos envuelven el ejercicio de la libertad de expresión de un enmarañado conjunto de condicionantes expresados en términos ambiguos e indeterminados, que dejan amplio margen de apreciación a los partidos y que se traducen en la realidad en que el ejercicio de la libertad de expresión de los militantes está sujeto a múltiples restricciones. La cuestión por tanto es si esta libertad está sujeta a un plus de restricciones por el mero hecho de ser quien la ejerce militante de un partido político si expresa opiniones políticas. La respuesta es afirmativa. Y en este sentido es de todo punto obligado traer a colación la STC 226/2016, de 22 de diciembre en relación a la crítica, de una militante del PSOE de Asturias a determinadas actuaciones y decisiones no se su partido en concreto sino de forma indeterminada, de todos los partidos. Concluye el Alto Tribunal que: «la intensidad de la crítica no justifica que (...) se utilicen expresiones que puedan legítimamente considerarse atentatorias contra la imagen externa del partido y de quienes lo dirigen, y que induzcan a la opinión pública a considerar que la propia organización no respeta el mandato constitucional de responder a una organización y funcionamiento democrático (...). De lo razonado se deduce que en el presente caso la demandante de amparo no observó en sus manifestaciones públicas las limitaciones derivadas del deber de lealtad ${ }^{90}$ hacia el partido al que pertenecía de forma voluntaria» (FJ 10).

La apelación de la lealtad, utilizada, como hemos visto, de manera profusa en los estatutos de los diferentes partidos, se erige en límite a la libertad de expresión de los militantes. No podemos más que disentir del sentido del fallo de esta sentencia. La

\footnotetext{
90 La cursiva es mía.
} 
demandante no hizo otra cosa que de forma un tanto provocadora o exagerada («mangantería», «verdulería», "personas que no tienen más oficio que el de tener la lengua muy marrón», etc.) denunciar un hecho que es generalizado a nivel de la opinión pública: la existencia de políticos profesionales, mediocres, acríticos y acomodados más preocupados por sus propios intereses que por defender los intereses generales, cargos que para ALZAGA «su única cualidad útil es la de la lealtad incondicional; el parlamentario ideal podría acabar por ser un perro de buena raza» ${ }^{91}$. No hay nada de novedoso en lo dicho por la militante del PSOE sancionada. El Tribunal de Estrasburgo, como recoge la propia sentencia del Tribunal Constitucional ampara lo que se dice y la forma como se dice permitiendo cierta dosis de exageración o provocación protegiendo aquello que moleste choca o inquieta siempre que esté relacionado con un asunto de interés general. El TEDH ha permitido las más amplias dosis de exageración o provocación cuando se trata de debate político. Creo que ni la idea que quería transmitir ni la forma en que lo hizo escandalizara a nadie por ser de utilización habitual. Las propias encuestas del CIS muestran, una y otra vez, como para los españoles los partidos políticos y la clase política son parte del problema y no de la solución $n^{92}$.

\section{4. ¿REALIDAD O MERA APARIENCIA?}

Que el poder fluya de abajo a arriba democratiza el partido. Todos los partidos se dotan de mecanismos en este sentido. El legislador, en su reforma de 2015, creyó cumplida la exigencia de dar la voz a la militancia con la modificación del apartado 1 del artículo 7 que exige la consulta a las bases para la elección de los principales cargos orgánicos.

El PSOE ha entendido cumplida la misión de dar mayor protagonismo a la militancia básicamente con la introducción de primarias, que parte del Comité Federal sea elegido por la militancia, y con las consultas del artículo 53 al que hemos hecho referencia. La militancia no juega un papel directo en la elección de los miembros de otros órganos. También el aparato del partido se reserva el control sobre la confección de las listas electorales. El Partido Popular es muy reacio a dar la voz a la militancia. Salvo para la elección del líder del partido, no se regulan cauces efectivos de participación de las bases. Como ejemplo puede traerse aquí a colación la reciente crisis del partido, febrero 2020, por el acuerdo en el País Vasco con la formación Ciudadanos en la que en ningún momento se planteó recurrir a la militancia para conocer su parecer e imponiendo la dirección nacional su criterio. Lo mismo podemos decir de

91 ALZAGA VIllaAmil, O. et alii, Derecho Político español según la Constitución de 1978 II, UNED, quinta edición, 2012, p. 357.

92 A título de ejemplo pueden verse el barómetro del CIS de enero de 2020. Entre los principales problemas se encuentran el mal comportamiento de los/as políticos/as $(18,3 \%)$ y lo que hacen los partidos políticos $(14,6 \%)$.

(C) UNED. Revista de Derecho Politico

N. ${ }^{\circ} 109$, septiembre-diciembre 2020, págs. 73-118 
Ciudadanos. Es más, en este partido encontramos un cierto retroceso al eliminar de sus últimos estatutos la posibilidad de que su Asamblea pueda ser de afiliados. En cuanto a Vox hay que decir que, aunque da protagonismo a las bases en la confección de los órganos del partido; sin embargo el partido controla la elaboración de listas electorales y de los distintos documentos del partido y no establece mecanismos efectivos de participación. Podemos es el partido que, sobre el papel, da mayor protagonismo a las bases: primarias, elección de diferentes órganos, confección de listas electorales, documentos, etc... Sin embargo, su actual liderazgo no carece de polémica y muchos disidentes han criticado la verticalidad y opacidad del partido acusando al núcleo duro de acallar a la militancia ${ }^{93}$.

Cabe cuestionarse si los partidos políticos, los nuevos y los viejos, que, vistos sus Estatutos, cuentan con un aparato fuerte y están altamente burocratizados, pueden y deben, a pesar de las nuevas tecnologías, consultar continuamente a la militancia antes de posicionarse sobre cuestiones de especial trascendencia no ya internas sino de gobierno. A ello podemos poner una serie de reparos. Los actuales partidos no son partidos de militantes sino de electores. La militancia que participa en esas consultas «no representa» al conjunto de electores del partido. La militancia para poder tomar una decisión racional ha de conocer a fondo la cuestión que se plantea lo que exige tiempo y dedicación y decidir en frio. Muy pocos tienen tiempo para ello, de ahí que los partidos justamente nacieran para generar representación. La política es el arte del debate y la negociación. La posición del partido, fruto de ellos, puede variar en pocas horas; las negociaciones para que fructifiquen necesitan de reserva, lejos de la luz y los taquígrafos ${ }^{94}$. Los partidos han optado por consultar a la militancia, en todo caso,

93 En este sentido pueden verse las declaraciones de Carolina Bescansa una de las piezas claves fundación de Podemos, tras los malos resultados de la formación en la autonómicas vascas y gallegas del pasado 12 de julio.

«La organización se ha vuelto vertical, pero no de abajo a arriba, sino de arriba abajo». «Una segunda característica de lo que ha pasado desde 2017, es la opacidad de los procesos internos, se han bloqueado todas las auditorías externas. Y, por último, el bloqueo a la militancia como fuente de propuestas políticas. La organización en Podemos se ha vuelto vertical, pero no de abajo a arriba, sino de arriba abajo». https://www.cuatro.com/todoesmentira/carolina-bescansa-critica-podemos-claves-derrota-electoral-companerismo-transparencia_18_2978070221.html. cuatro.com

13/07/202017:05h-

94 Lejos queda, enero de 2016, la intención del PSOE y Podemos de negociar «con luz y taquígrafos», «en público» y hasta «en streaming». «¿Cumplirán Sánchez e Iglesias la promesa de retransmitir en directo las negociaciones?». https://www.elplural.com/politica/cumpliran-sanchez-e-iglesias-la-promesa-de-retransmitir-en-directo-las-negociaciones_76185102 Miércoles, 3 de febrero de 2016. Elecciones generales 201: «Cuando Sánchez e Iglesias defendían negociar acuerdos «con luz y taquígrafos» y «en streaming»». https://okdiario.com/espana/cuando-sanchez-iglesias-defendian-negociar-acuerdos-luz-taquigrafos-streaming-4807663. 12/11/2019 21:25

En 2020, en cambio, podemos leer: «Investidura parlamentaria. Las claves de la negociación secreta entre el PSOE y Unidas Podemos. «Las conversaciones para acordar el Gobierno de coalición se llevaron con total discreción mientras el foco mediático se centraba en el diálogo con ERC». https://elpais. com/politica/2019/12/23/actualidad/1577123453_900388.html. 1 ENE 2020 - 16:32 CET 
el fruto final de la negociación pero no su desarrollo. Si los militantes no apoyan lo decidido por el aparato, éste quedará claramente debilitado; para evitarlo, éste puede caer en la tentación de plantear la pregunta en términos tales que obtenga el resultado deseado.

PSOE y Podemos han recurrido en más de una ocasión a la militancia. Así, en relación a la formación de gobierno, el 23 de noviembre de 2019, el PSOE preguntó a sus militantes por el acuerdo alcanzado con Unidas Podemos para formar un gobierno de coalición. Ello no obstante, el pacto con Esquerra Republicana para asegurarse la abstención de ésta última formación, no fue sometido a consulta de la militancia sino que simplemente fue ratificado el 3 de enero de 2020 por la ejecutiva del PSOE a pesar de la polémica desatada al contemplar la realización de una consulta legal sobre la relación de la comunidad autónoma con el resto de España y no figurar en los términos del acuerdo ninguna referencia expresa a la Constitución conteniendo simplemente una referencia genérica al «respeto a los principios que rigen el ordenamiento jurídico democrático». Este segundo caso ni se consideró acuerdo de gobierno ni una cuestión de especial trascendencia por lo que la militancia no fue consultada.

De acuerdo con el artículo 484 del Reglamento Federal de Desarrollo de los Estatutos, de febrero 2018, «la votación en la consulta será mediante voto individual, directo y secreto de los y las militantes y afiliados/as». En este contexto cabe situar la polémica surgida en julio de 2017 en Castilla La Mancha sobre si se debiera haber consultado a la militancia del PSOE la entrada de Podemos en el gobierno de la Comunidad. En este caso se acordó consultar a las bases, pero sin votación con urnas. Se convocaron asambleas en todos los municipios donde se debatió el pacto pronunciándose a continuación. De esta manera se obtuvo un alto respaldo a la propuesta oficialista encabezada por el Presidente de Castilla-La Mancha, García-Page. ${ }^{95}$

No es ningún secreto que la dirección del partido puede prefabricar la pregunta con el fin de facilitar, cuando no conseguir, el respaldo a su propuesta. Así, por ejemplo fue criticada la fórmula empleada por Podemos para preguntar a la militancia sobre el acuerdo de gobierno con el PSOE en Castilla la Mancha en julio de $2017 \mathrm{al}$ no preguntar directamente sobre un acuerdo de gobierno sino por el apoyo a los presupuestos mediante una formula larga y poco clara ${ }^{96}$. En julio de 2019 se criticó también la fórmula con que la dirección de Podemos planteó a la militancia apoyar

95 «Más del $90 \%$ de los militantes del PSOE en Castilla-La Mancha apoya el pacto de García-Page con Podemos». https://www.elmundo.es/espana/2017/08/01/59806b4646163ff0758b45bb.html. Madrid, 1 AGO. 2017 13:52.

96 La pregunta, que planteaba de forma conjunta a los militantes la aprobación del presupuesto y la entrada en el Gobierno, era la siguiente: «¿Crees que Podemos Castilla-La Mancha debería votar sí a los presupuestos si con un acuerdo de gobierno se garantiza la puesta en marcha y el control de políticas propias como la Renta Garantizada o el Plan de Garantías Ciudadanas?». Pregunta «enrevesada» para algunos medios. https://www.elindependiente.com/politica/2017/07/20/psoe-podemos-ocultangobernaran-juntos-consultas-los-militantes/. Publicado el 20/07/2017Actualizado el 21/07/17 - 12: 35 
la investidura de Pedro Sánchez ${ }^{97}$. Solo contemplaba los términos del 'sî' al candidato del PSOE, ya fuera mediante un Gobierno de coalición o facilitando uno monocolor y de «cooperación», obviando otras opciones como podría ser el «no» a la investidura, lo que fue objeto de crítica incluso dentro de su partido ${ }^{98}$. De igual manera, mientras en esas fechas el POSE preguntaba expresamente por el acuerdo alcanzado entre la formación y Unidas Podemos ${ }^{99}$, en febrero de 2016 la pregunta sobre el acuerdo de gobierno de la formación con Ciudadanos fue realizada en términos genéricos sin referencia expresa a la otra formación política. ${ }^{100}$

Por otra parte, tampoco queda claro cuando se obtiene el respaldo de la militancia. No se exige un mínimo de participación lo que plantea la cuestión de hasta qué punto una decisión de estas características quede en manos de una minoría. Si acudimos al acuerdo de gobierno suscrito entre PSOE y Ciudadanos el 24 de febrero de 2016, la participación en el PSOE fue del 51,6\%, siendo ratificado el acuerdo por el $79 \%$ de los militantes lo que supuso un $40 \%$ de apoyo expreso a dicho acuerdo. Más recientemente en la Consulta de Podemos en julio de 2019 sobre el apoyo a la investidura del candidato del PSOE, Pedro Sánchez, solo participó un $26 \%$ de las bases de la formación, obteniendo la propuesta del líder Pablo Iglesias el respaldo del $70 \%$ de los votantes.

97 La pregunta era la siguiente, con dos opciones: «¿Cómo deben votar las diputadas y los diputados de Podemos en las sesiones de investidura de la XIII Legislatura?

1) Para hacer presidente a Pedro Sánchez es necesario llegar a un acuerdo integral de gobierno de coalición (programático y de equipos) sin vetos, donde las fuerzas de coalición tengan una representación razonablemente proporcional a sus votos.

2) Para hacer presidente a Pedro Sánchez, ya sea mediante el voto a favor o mediante la abstención, basta con la propuesta del Partido Socialista: un gobierno diseñado únicamente por el PSOE, colaboración en niveles administrativos subordinados al Gobierno y acuerdo programático».

98 Ahí están las declaraciones de Teresa Rodríguez, líder de la formación en Andalucía que consideraba que la pregunta: «olvida otras opciones posibles y es, lamentablemente, un verdadero insulto a la inteligencia que denota falta de confianza en los argumentos que se tienen para defender un pacto a toda costa». https://www.rtve.es/noticias/20190712/podemos-consulta-basespacto-psoe-investidura-gobierno/1970553.shtml. 12.07.2019| 19:10 horas

99 La pregunta estaba formulada en los siguientes términos: «¿Apoyas el acuerdo alcanzado entre el PSOE y Unidas Podemos para formar un Gobierno progresista de coalición?» Con una participación del $63 \%$ obtuvo un respaldo del $92 \%$.

100 La pregunta estaba formulada en los siguientes términos: «El PSOE ha alcanzado y propuesto acuerdos con distintas fuerzas políticas para apoyar la investidura de Pedro Sánchez a la presidencia del Gobierno. ¿Respaldas estos acuerdos para conformar un gobierno progresista y reformista?. Para algún medio, «la pregunta era muy ambigua y el acuerdo con Ciudadanos no había despertado un gran entusiasmo» https://www.elmundo.es/espana/2016/02/27/56d1fc92268e3e21228b45e1.html. 27/02/2016 21:48. https:/elpais.com/politica/2016/02/27/actualidad/1456568372_746890.html. Madrid 29 FEB 2016 - 12:00 CET. «La pregunta a la que tenían que responder con 'sí o 'no' no ha convencido a los sectores más críticos, que han llegado a calificarla de «trampa» o farsa». https://www. eldiario.es/politica/Ferraz-militantes-participado-consulta-Ciudadanos_0_488901494.html. 27/02/2016 - 20:31h 
A veces esa consulta a la militancia se ha hecho en relación a cuestiones un tanto extravagantes. Ahí está la planteada a los militantes de Podemos sobre la continuidad en los cargos de Pablo Iglesias e Irene Montero a raíz de la polémica compra de su vivienda en Galapagar. La consulta fue promovida por ambos y tuvo lugar entre los días 22 y 27 de mayo de 2018. Ello no obstante, en la consulta no se mencionaba el ya famoso chalet sino que simplemente se preguntaba por la credibilidad de ambos líderes ${ }^{101}$. Con récord de participación, las bases ratificaron a ambos en sus cargos por un $68,42 \%$.

De entrada, llama la atención que la reforma de la Ley Orgánica de Partidos Políticos, llevada a cabo en 2015, no introdujese entre los derechos de los afiliados el de la libertad de expresión. Si lo hacen los partidos de forma expresa, a excepción de Podemos que ha eliminado su referencia en los nuevos Estatutos, aunque puede deducirse de su contenido. En todo caso, el derecho queda restringido al ámbito interno. Obligado es, en este sentido, hacer referencia a la Propuesta de Reforma de la Ley de Partidos Políticos elaborada por el grupo +Democracia en octubre de 2013 (previa, por tanto, a la reforma de la LOPP) en cuyo artículo 12, intitulado «Derecho a la libertad de expresión y de información» se garantizaba en su punto 1 a los miembros de los partidos políticos «su derecho a la libertad de expresión, tanto en el interior de los partidos como en su acción política en la sociedad».

El partido necesita lanzar cara al exterior un mensaje unitario, alejado de controversias internas, de lo contrario pierde «competitividad». Como advierte LINZ, el partido necesita unidad y no mostrar fisuras o faccionalismos pues el votante castiga si el debate interno genera división ${ }^{102}$. Puede resultar paradójico que el debate interno, signo de democracia interna, sea visto con reticencia por el electorado. Los partidos políticos usan y abusan de términos abiertos e indeterminados a la hora de asfixiar la libertad de expresión de los militantes. En nada ayuda la sentencia del Tribunal Constitucional 226/2016, de 22 de diciembre, que viene a fortalecer la posición del aparato del partido sobre el militante y que refuerza al primero en su labor de conseguir una lealtad acrítica, impropia de un sistema democrático. Si a ello sumamos que el aparato del partido controla el órgano llamado, en teoría, a garantizar los derechos de los afiliados frente a éste pero que, en realidad, es el órgano ejecutor, en muchas ocasiones, del disidente, la conclusión es que realmente los partidos no desean que el mensaje escape de su control.

Por otro lado, consultar a la militancia sobre cuestiones de gobierno no deja de ser un ataque al principio de representación. La militancia ya ha hablado al votar, a partir de ese momento deberían ser los cargos representativos los que tomaran el relevo. Ello no obstante, tampoco hay que llamarse a engaño. De no consultarse a la militancia ello no quiere decir que el representante sea libre a la hora de votar esas

101 La pregunta estaba formulada en los siguientes términos: «¿Consideras que Pablo Iglesias e Irene Montero deben seguir al frente de la secretaría general de Podemos y de la portavocía parlamentaria?».

102 LINZ, J.J., «Teoría de la democracia. Los problemas de las democracias..., op. cit., p. 242. 
cuestiones de gobierno. El partido impone de facto un mandato imperativo. Aunque este trabajo está dedicado a analizar los instrumentos con los que cada partido dota a la militancia para que ésta tenga voz en la toma de decisiones o en dar su opinión sobre las más diversas cuestiones llegándose a la conclusión de que realmente el poder sigue fluyendo de arriba abajo es conveniente, por último, ver qué sucede con los cargos representativos. En estos casos se observa como el partido ejerce una férrea disciplina, castrense la califica TORRES DEL MORAL ${ }^{103}$, sobre los cargos representativos. En nuestro sistema actual de listas cerradas y bloqueadas y de absoluta y férrea disciplina de partido, la ciudadanía se pregunta a quién pertenece el escaño, si al electo, al partido político, o a la lista. El electorado se inclina por unas siglas y, en todo caso, por un líder, pero no por unas personas que, en la mayoría de las ocasiones, no ha visto en su vida y cuyo nombre ni recuerda. Es difícil explicar al electorado que un concejal o un diputado vaya por libre y que tenga la posibilidad de conservar su escaño tras alinearse con la oposición en una moción de censura derrocando al alcalde o al gobierno de turno. Lo advertía KELSEN en 1920: «en los casos de sistema electoral por listas (...) los electores no designan al diputado por su persona, sino que su voto más bien significa un acto de adhesión a un partido político determinado, de manera que el candidato obtiene su representación sólo en virtud de su filiación al partido del elector, siendo lógico que el diputado pierda su mandato tan pronto deje de permanecer al partido que le ha enviado al Parlamento» ${ }^{104}$. Este debate surge cada vez que salta a los medios de comunicación un caso de transfuguismo político ${ }^{105}$. Estos casos comportan reacciones que refuerzan la autoridad y presencia de los partidos políticos en la vida pública. A fin de acabar o, al menos minimizar, el fenómeno del transfuguismo se han dictado normas o suscrito acuerdos que buscan acabar con el disidente equiparando tránsfuga a no adscrito cuando son dos figuras diferentes. Se puede ser no adscrito sin haber sido tránsfuga. ${ }^{106}$. Los partidos han intentado acabar

103 TORRES DEL MORAL, A., «La crisis del mandato representativo en el Estado de Partidos», Revista de Derecho Político, no 14, 1982, p. 17.

104 KELSEN, H., Esencia y valor de la democracia, Labor, 1934, p. 69. Con ocasión del caso de Tamayo y Sáez, RUBIO LLORENTE, tras observar lo sucedido en los últimos años, afirmaba de forma un tanto resignada que el esfuerzo por lograr que la estructura real de la representación se acomodara a la teoría clásica de la misma, «liberándola del abrazo asfixiante de los partidos (...), parece ya hoy sin embargo ilusorio y vano» siendo «inútil seguir luchando por ajustar la realidad a una idea que no tiene soporte alguno en la conciencia social; que no es creencia, sino puro diseño teórico». RUBIO LLORENTE, F., «Vernos como somos», El País, 21 de junio de 2003.

105 Sobre esta cuestión vide, por todos, DE ESTEBAN, J., «El fenómeno español del transfuguismo político y jurisprudencia constitucional», Revista de Estudios Políticos, 1990, núm. 70; PRESNO LINERA, M. A., «La superación del transfuguismo político en las corporaciones locales como exigencia de una representatividad democrática», Revista de Estudios de Administración Local y Autonómica, 1998, núm. 271; TOMÁS MALLÉN, B., Transfuguismo parlamentario y democracia de partidos, Centro de Estudios Políticos y Constitucionales, 2002; y SANTAOLAYA MACHETTI, P. y CORONA FERRERO, J. M ${ }^{\mathrm{a}}$ (Dirs.), Transfuguismo político: escenarios y respuestas, 2009, Civitas.

106 En el ámbito local se han llevado a cabo dos reformas legislativas. En 2003, se reforma el artículo 73.3 LBRL y en el 2011, el artículo 197 LOREG (declarada inconstitucional por STC 151/2017, 
con este último, pero también con el representante disidente, con el llamado, en ocasiones, verso libre. Se busca que el representante no tenga opinión propia y que, de forma disciplinada, vote siguiendo las directrices del partido. ¿Cómo logra un partido controlar al cargo político elegido en las urnas? Entre otras formas, siendo estable y duradero en el tiempo, con una débil democracia interna, sometiendo a sus cargos representativos a una férrea disciplina, con un sistema de cooptación de los candida$\operatorname{tos}^{107}$ anudado a un sistema de listas cerradas y bloqueadas y con unas campañas electorales caras que sólo puede sufragar el partido. Con ello, el partido asegura su dominio sobre el representante político, que está más interesado en lo que sucede intra partido que extra partido y en agradar al establishment para asegurarse un sitio en las listas en los siguientes comicios ${ }^{108}$. Para SARTORI la existencia de la disciplina de partido no supone, per se, una negación de la democracia dentro del partido, siempre y cuando se haya podido discutir y debatir antes de forma abierta en las estructuras del partido el posicionamiento a adoptar ${ }^{109}$. Como marco teórico no hay nada que objetar, pero la tónica general es la falta de discusión y debate en el seno de los grupos

de 21 de diciembre. También en este ámbito encontramos el Acuerdo sobre un código de conducta política en relación con el transfuguismo en las corporaciones locales de 7 de julio de 1998, renovado el 26 de septiembre de 2000 y el 23 de mayo de 2006. En relación a representantes parlamentarios, mientras que los Reglamentos del Congreso y del Senado no contemplan la figura del diputado o senador no adscrito por lo que el representante que deja de pertenecer a su grupo parlamentario ya sea de forma voluntaria ya sea por expulsión, pasa a formar parte del grupo mixto. Los reglamentos de los parlamentos autonómicos contemplan la figura del concejal no adscrito. Así, por ejemplo, el Reglamento de Les Corts Valencianes recoge en su artículo 27 la figura del diputado no adscrito al que somete a un estricto régimen. De este modo, por ejemplo, el artículo 28 señala que «los diputados o diputadas no adscritos gozarán únicamente de los derechos reconocidos reglamentariamente a los diputados o diputadas individualmente considerados». Con la excusa de hacer frente al transfuguismo, de forma soterrada se refuerza el poder de los partidos políticos sobre los representantes trasladando el mensaje de que hay que ser disciplinado, pues fuera del partido la situación del cargo es muy precaria. Como afirma SÁNCHEZ NAVARRO, «quien no tiene Grupo apenas existe, parlamentariamente hablando». SÁNCHEZ NAVARRO, A. J., «Representación nacional y grupos parlamentarios en el Congreso de los Diputados», Cuadernos de Pensamiento Político, núm. 12, , 2006, p. 99.

107 Vide el estudio del CIS sobre élites políticas en España 2009-2011. A la pregunta ¿Cómo se produjo su elección para ir en las listas?, el 77\% contestó: me lo ofrecieron. A la pregunta ¿Quién o quiénes le propusieron para ir en las listas electorales en un puesto de elección? El $85 \%$ contestó: órganos o cargos del partido; solo un $2 \%$ contestó que las bases. A la pregunta ¿cuánto poder tienen en su partido los grupos siguientes para seleccionar candidatos para el parlamento? El 76\% contestó: los líderes, ya fueran nacionales, autonómicos o locales; y solo un $5.4 \%$ contestó que los afiliados. Una clara muestra del carácter oligárquico de los partidos. http://www.cis.es/cis/export/sites/default/-Archivos/ Marginales/2820_2839/2827/Es2827.pdf.

108 En este sentido señalaba TORRES DEL MORAL en 1982 que las vinculaciones partidistas del representante tienden a ser más fuertes que cualesquiera otras (incluyendo las de su clase social). TORRES DEL MORAL, A., «La crisis del mandato representativo en el Estado de Partidos», Revista de Derecho Político, núm. 14, 1982, p. 14.

109 SARTORI, G., Ingeniería constitucional comparada, Fondo de Cultura Económica, México, 1994, 210. Vide igualmente RAMIREZ, M., «Teoría y práctica del grupo parlamentario», Revista de Estudios Políticos, núm. 11, 1979, p.20.

(C) UNED. Revista de Derecho Politico

N. ${ }^{\circ} 109$, septiembre-diciembre 2020, págs. 73-118 
municipales o parlamentarios. La uniformidad en el voto, dirá este autor, es un mal necesario pero sólo ella asegura la estabilidad del sistema ${ }^{110}$. Logrará la estabilidad, pero se corre el peligro de convertir nuestra democracia, utilizando una afortunada expresión de CAAMAÑO, en una democracia de mesa de camilla ${ }^{111}$. No es aquí el lugar para abrir un debate sobre nuestro sistema electoral pero a la hora de analizar sus consecuencias no deseadas habría que reflexionar sobre si sería conveniente propiciar la aparición de figuras similares al backbencher propio del parlamento británico; el diputado que se sienta en los escaños de atrás, que no forma parte del gobierno ni del núcleo duro del partido, que parece tener poca influencia pero que en un momento dado muestra su disconformidad con las directrices del partido pues ha de responder ante su electorado, en su oficina radicada en su circunscripción, del voto emitido. No es raro, todo lo contrario, ver en la Cámara de los Comunes que diputados del partido en el gobierno votan contra las propuestas de éste.

Title:

A new way to make politics: giving the voice to the militancy. Reality or mere appearance?

\section{Summary:}

1. THE PROBLEM: POLITICAL PARTIES' EXCESSES. 2. THE SOLUTION: GIVE VOICE TO THE PARTIES' MEMBERS. 2.1. Members assembly or delegates congress 2.2. Primaries: the panacea for all problems? 2.3. Election for other positions. 2.4. The participation of the members of the party in the elaboration of political documents. 2.5. The role of membership in the elaboration of the electoral lists. 2.6 Other mechanisms of direct democracy and participatory democracy. 3. FREEDOM OF EXPRESSION OF THE MEMBERS OF THE PARTY. 4. REALITY OR JUST APPEARANCE?

\section{Resumen:}

Se ha tachado a los partidos políticos de estar controlados por una élite o casta que ha mirado más por sus propios intereses que por los intereses generales. Ha aparecido una nueva forma de hacer política y nuevos partidos

\footnotetext{
110 Idem p. 209.

111 CAAMAÑO DOMÍNGUEZ, F., «El escaño de Tamayo y la democracia de mesa camilla», El País, 17 de julio de 2003.
} 
cuyo objetivo declarado ha sido devolver la voz a la militancia dando por sentado que ésta había sido secuestrada por las élites endogámicas de los partidos. Este trabajo analiza si verdaderamente los partidos, cuyo poder se ha construido tradicionalmente de arriba a abajo, han asumido este cambio que comportaría que el poder fluya de abajo arriba o simplemente se ha llevado una operación cosmética que en apariencia responde a esa nueva forma de hacer política, aunque realmente el poder sigue en manos de una minoría.

\begin{abstract}
:
Political parties have been accused of being controlled by an elite or caste that has looked more for their own interests than for general interests. A new way of doing politics and new parties has appeared whose stated objective has been to return the voice to the militancy, assuming that it had been kidnapped by the inbreeding elites of the parties. This paper analyses whether the parties, whose power has traditionally been built from top to bottom, have assumed this change that would mean that power flows from the bottom up or has simply taken a cosmetic operation that apparently responds to this new way of doing policy, although the power is still in the hands of a minority.
\end{abstract}

\title{
Palabras clave:
}

partidos políticos; élites; militancia; Democracia interna; Regeneración democrática.

\section{Keywords:}

Political parties; Elites; Militancy; Internal democracy; Democratic regeneration. 
